\title{
Geology and Trace Element Geochemistry of the Barite-Copper Mineralization in Gulani Area, NE Nigeria
}

\author{
Jalo Muhammad EL-Nafaty \\ Department of Geology, University of Maiduguri, Nigeria.
}

\begin{abstract}
The geology of Gulani area is composed of Precambrian basement complex of the Older Granite suit (diorite and granites), the Cretaceous sediments of Bima, Yolde and Pindiga Formations and the Tertiary/Quaternary basalts of the Biu Plateau. Epigenetic barite-copper mineralization with barite associated with sandstones and copper occurring in granites have been mapped in the area. Unaltered (distal), hydrothermally altered (proximal) host rocks and barite and chalcopyrite/malachite mineral separates were sampled and investigated petrographically and geochemically for their trace element abundances. Reflected light microscopy of the Cu-mineralized granites show that chalcopyrite constitutes the primary sulphide veins/veinlets materials which altered to malachite and its associated limonite through the processes of hydrolysis and oxidation. Trace element geochemistry reveals that barite mineralization areas are characterized by remarkable enrichment of $\mathrm{Ba}$ and $\mathrm{Sr}$ and depletion of $\mathrm{Rb}$ from the distal sandstones through the proximal sandstones to the barite vein materials where the Ba content is >500,000 ppm (>50\%). In the copper mineralization areas, $\mathrm{Cu}$ is enriched to values $>10,000 \mathrm{ppm}(>1 \%)$ in the copper mineralized granites and chalcopyrite/malachite separate. However, the Cu mineralization is accompanied by depletion of $\mathrm{Ba}, \mathrm{Sr}$ and $\mathrm{Rb}$ and enrichments of $A g, U, V, Z r, P b$ and Y.There are therefore, remarkable contrasts in respect of the trace elements behavior and abundances between barite and copper mineralization areas probably due to the variations in fluids origin, fluids and host rock compositions (sandstones and granites), the chemical activities (intensities) and temperatures of the hydrothermal fluids responsible for the deposition of barite and copper deposits.
\end{abstract}

Keywords: barite-copper, Gulani, mineralization, Nigeria, Petrography, trace elements.

\section{Introduction}

The study area is located within the southern parts of Borno and Yobe states in the north eastern part of Nigeria. It lies within the Gongola Basin of the Upper Benue Trough which comprises of basement complex rocks, Cretaceous sediments and Tertiary/Quaternary volcanics of the Biu plateau (Fig 1). The basement complex rocks consist of migmatite-gneiss complex and the Older Granites. The oldest rocks in the region are made up of remnants of an ancient sedimentary series now almost entirely transformed into anatectic migmatites, gneisses and granites through migmatization and granitization processes. Relicts of the metasediments include quartzo-feldspathic, biotite- and hornblende-gneisses, quartzites, marbles and calcsilicate rocks found as small pendants and xenoliths in the granitic rocks. Carter et al., 1963, reported that the mineral assemblages correspond to those of the amphibolites facies. The Pan African (500 $\pm 150 \mathrm{Ma}$ ) Older Granites series are widespread and consists of three phases distinguished as basic and intermediate plutonic rocks, fine grained granites and syntectonic granites (carter et al., 1963). The basic and intermediate plutonic rocks which include small irregular bodies of gabbro, quartz-diorite and granodiorite are of wide occurrence. The fine-grained granites are however, minor discordant intrusions of small extent. The syntectonic granite group on the other hand constitutes the largest part of the basement. The group comprises of diverse series of potassic rocks including anatectic migmatite, equigranular and porphyritic granites. They show numerous variations in structure, texture and mineralogy and exhibit several phases of transition between the members (carter et al., 1963). 


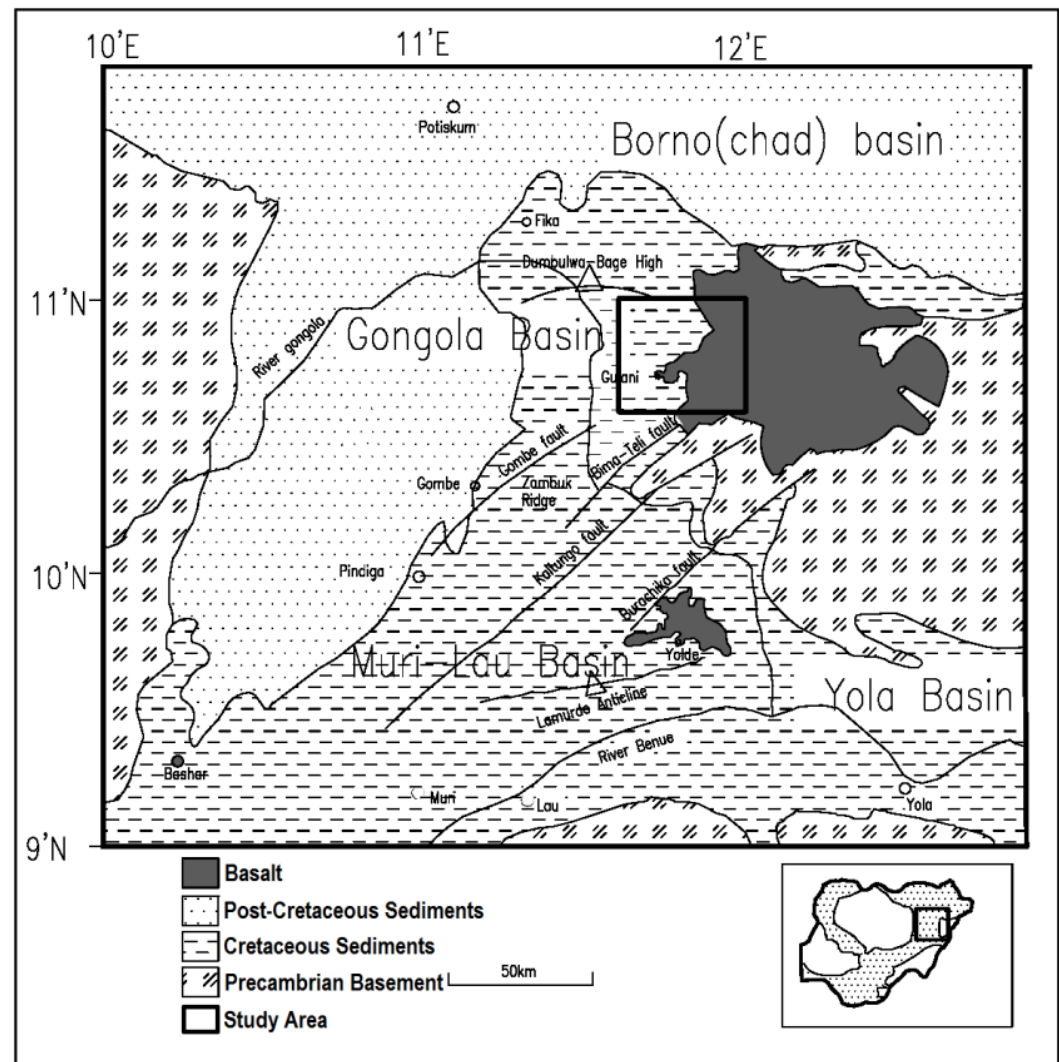

Fig. 1. Geological Map of the Upper Benue Trough showing the study area within the Gongola Basin (modified after Zaborski et al., 1997).

The basement complex is nonconformably overlain by the Cretaceous sediments of the Upper Benue Trough which is divided into three sub-basins namely; the N-S trending Gongola sub-basin; the WNW-ESE Yola Sub-Basin (Arm) and the Muri-Lau Basin trending N55 E ( Fig. 1). The sedimentary litho stratigraphic pile in the Gongola Sub-Basin started in Aptian-Albian with the deposition of the Bima group (Popoff et al., 1986 and Zaborski et al., 1997). It comprises of largely sandstone and clay series deposited in a lacustrinedeltail environment. The sediments consist mainly of poorly sorted, angular, highly arkosic pebbly sandstones, granulestones and pebble conglomerates (Zaborski et al., 1997). The Bima group is succeeded by beds of Cenomanian Yolde Formation comprising of variable sequence of sandstones, shales and mudstones. The formation is a transitional sequence between the continental Bima group and the marine deposits of the lower part of the Pindiga Formation. Above these transitional sequence beds is a marine sequence of shales with interbedded carbonates representing the Turonian and Senonian stages. Zaborski et al., 1997 recognized five members of the Pindiga Formation in the Gongola Sub-Basin. There are from top to bottom: The Fika Member; Dumbulwa Member; Deba Fulani Member; Gulani Member and Kanawa Member. They noted that the Gulani, Deba Fulani and Dumbulwa Members are lateral lithofacies equivalent occurring in the middle part of the Pindiga Formation. The Cretaceous sequence is capped by the regressive Gombe Formation of Maastrichtian age. It comprises of alternating beds of sandstones, silty shales, clay and flaggy ironstones while the top of the sequence is always capped by ironstones. The western part of the Benue Trough is covered by the continental Paleocene Kerri-Kerri Formation which lies unconformably over the Gombe Formation. The formation consists of continental sequence of grits, sandstones and clays. It is capped by oolitic or vesicular ironstones (carter et al.,1963). The Cretaceous Gongola Sub-Basin is concealed in the extreme east by the Tertiary/Quaternary basalts of the Biu Plateau.

Epigenetic barite-cupper veins have been mapped in Gulani area where the barite veins were found to be associated with the Cretaceous sandstones while the cupper mineralizations were restricted to the Pan African granites. These mineralizations together with other baryte occurrences in Gombe, Alkaleri and Didango all in the Upper Benue Trough are believed to be part of the $\mathrm{Pb}-\mathrm{Zn}-\mathrm{Cu}-\mathrm{F}$ metallogenetic belt of the Benue Trough (Farrington,1952; Olade, 1976; Olade and Marton, 1980, Ford, 1989 and wright, 1989).The belt which is about $80 \mathrm{~km}$ wide extends for about $600 \mathrm{~km}$ from Abakaliki in the south west of the trough to Gombe in the north east. Three mineralized zones have been located in this belt with $\mathrm{Pb}-\mathrm{Zn}+\mathrm{Cu}$ of Abakaliki district in the lower Benue Trough; The Arufu Akwana Pb-Zn-F+Ba district in the middle Benue Trough and the ZurakGwana-Gombe $\mathrm{Pb}-\mathrm{Zn}+\mathrm{Ag}$ district in the Upper Benue Trough (Olade and Marton, 1980; Akande and Abimbola 
1987; Ford 1989; RMR\&DC, 2004 and Abaa, 2009). Several barite occurrences some of which are of economic significance are known in the Middle Benue such as Aloshi, Keana, Azara, Akiri, Wuse, Chiata, Ibi, Gbande and Gboko areas (Tate, 1959; Ajayi, 1987; Akande and Abimbola, 1987; Adubok and Imoekparia, 2008 and Chaanda et al., 2010). This study deals with detailed petrography and trace element characteristics of the baritecopper mineralizations of the Gulani area.

\section{Materials And Methods}

The geological mapping of the Gulani area was carried out using the 1: 50,000 topographic base maps representing Gulani sheet 132, NE, SE, NW and SW. A total area of $2093 \mathrm{~km}^{2}$ was covered using traverse mapping method with the aid of compass and Global Positioning System (GPS) for the accurate location of outcrops and other features. The resultant geological map was digitized using Geographical Information System (GIS) utilizing ArcGis 9.3 and Integrated Land and Water Information System 3.3 (ILWIS). The detailed geological maps of the barite-copper mineralization areas were also digitized. Eighty nine (89) representative rock samples from the various rock units including those of the mineralization areas were thin sectioned for transmitted light microscopy. In addition ten (10) polished block sections of $\mathrm{Cu}$ mineralized granites were prepared for reflected light ore microscopy. Both the polished and thin sections were prepared at the Laboratory of the Department of Geology, Ahmadu Bello University, Zaria, Nigeria. The petrographic studies were carried out at the laboratories of the Departments of Geology, University of Maiduguri; and Kano State University of Science and Technology (KUST), Wudil. Thirty samples of vein materials and their host rocks were analyzed for trace element abundances at Activation Laboratories Ltd (ACTLABS), Ancaster, Ontario, Canada. Samples were fused with metaborate/tetraborate and subsequently analysed using Inductively-Coupled Plasma-Mass Spectrometry (ICP - MS) analytical technique.

\subsection{General Geology and Petrography}

\section{Results}

The Gulani area is underlain by the basement complex rocks, some Cretaceous sedimentary formations and the Tertiary/Quaternary basalts of Biu Plateau (Fig. 2). The basement complex rocks identified are members of the Older Granite series which occur as inliers of generally restricted occurrences and are surrounded by the Cretaceous sediments and the Tertiary/Quaternary basalts. The Cretaceous rocks are restricted to the western part while the basaltic flows overlie the eastern part of the study area (Fig. 2). A summary of the geology and petrography of the rocks is here presented while detailed description is given in El-Nafaty, 2014 and El-Nafaty, 2015a.

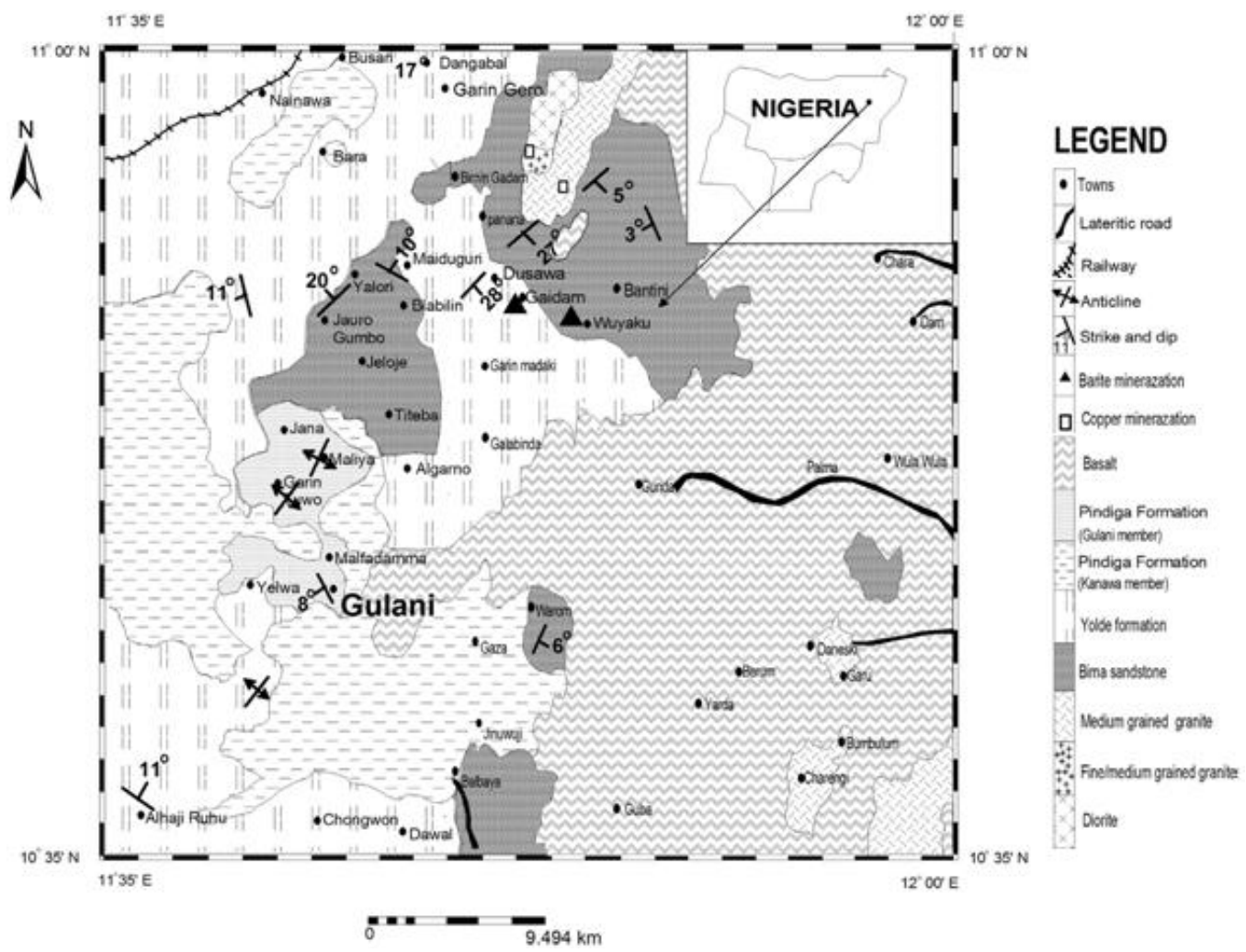

Fig. 2. Geological Map of Gulani area (After El-Nafaty, 2014). 
The diorite forms low to intermediate lying hills and also occurs as large scattered boulders. It is dense melanocratic massive medium grained rock. Microscopic study indicates that the rock is largely composed of andesine $\left(\mathrm{An}_{35}\right)$ with subordinate hornblende and accessory quartz and opaques. The granites are fine-medium and medium grained rocks that are mainly pinkish sand grey in colour. They form low to high hills but sometimes occur as scattered boulders. The rocks are composed of quartz, microcline, orthoclase plagioclase, flaky biotite, quartz and accessory zircon and opaque minerals. The large crystals of quartz and microcline are highly fractured. The Garin Gero Copper mineralization (GCM1 and GCM2) are hosted by granites.

The Bima sandstone which is the oldest of Cretaceous sediments overlies nonconformably the basement complex. It occurs as continuous range of hills in some places while other areas are underlain by flat lying outcrops and plains. It forms massive thick beds consisting mainly of medium grained cream, whitish, grey feldspathic sandstones. When weathered the rock appears reddish or brownish. Field and microscopic investigation of the rock shows that it consists of quartz, microcline, plagioclase, biotite and opaques. The large quartz and microcline are fractured and the Wuyaku barite mineralization (WBM) is hosted by Bima sandstone. The Yolde Formation is generally poorly exposed and gives rise to subdued topography. However, there are some areas represented by flat topped medium lying hills. The formation comprises of thin alternating sequence of mostly fine grained sandstones, siltstones, mudstones and in few instances medium grained sandstones and shale. The sandstones consist of quartz and microcline with accessory opaques. The Gaidam barite mineralization is hosted within this formation. The Pindiga Formation is represented by Kanawa and Gulani members. The Kanawa member is generally represented by low lying topography. It comprises mainly of shale which in places are interbedded with limestone beds. The shale appears grey or dark coloured while the limestones are mostly grey but light brownish colors are encountered. The limestones are either fossiliferous or crystalline. The crystalline limestone is typically composed of calcite, quartz, dolomite, plagioclase and microcline while the fossiliferous type in addition to calcite and dolomite contains some pelecypods. The Gulani member occurs mainly as hills comprising of sequence of medium grained sandstone, fine grained sandstone and siltstone. Some of the hills are made up of entirely medium grained sandstone which in few cares is massively bedded. The colour of the sediments vary from light grey, dark grey, cream, whitish to light brown. The sandstones are composed of quartz, microcline, calcite with subordinate opaques and plagioclase.

The basalt occupies the escarpments, hills or ridges are generally represented by large boulders. Other areas of coverage occur as elevated or flat landscape occupied by scattered or densely packed large or small boulders and fragments of the basalt. The basalts occur as massive or vesicular dark, grey or dark grey coloured rocks. Some of the rocks contain small and relatively large olivine nodules while the vesicles are occupied by calcite or zeolite. Microscopic observation indicates that rock is composed of plagioclase laths, olivine, augite and opaque minerals.

\subsection{Geology and Petrography of the Mineralisation areas}

Four barite-copper mineralization areas have been located in Gulani area. These are the Gaidam and Wuyaku barite mineralization (GBM and WBM) and the Garin Gero Copper Mineralization areas 1 and 2 (GCM1 and GCM2).

\subsubsection{Baryte Mineralization Areas (GBM and WBM)}

The GBM is located within the Yolde Formation while the WBM occurs in Bima sandstone. The GBM area is flat-lying with poor exposures. The barite mineralization is associated with the fine grained sandstones. The mineralization occurs as two sub-parallel veins both striking $014^{0}$ and $80 \mathrm{~m}$ apart (Fig. 3) are similar in characteristics. The lager vein is $75 \mathrm{~m}$ long and $3.5-5 \mathrm{~m}$ wide while the second one is $25 \mathrm{~m}$ long and about 3.5 $\mathrm{m}$ wide. The barite occurs as massive material having hardness of 3 on mohrs scale. Its densities vary from 4.47 $-5.58 \mathrm{~g} / \mathrm{cm}^{3}$. The petrography of the unaltered Yolde Sandstones (distal) has been described earlier. However, the hydrothermally altered sandstone (proximal to barite mineralization) consists of quartz, barite, microcline and plagioclase (Fig. 4). 


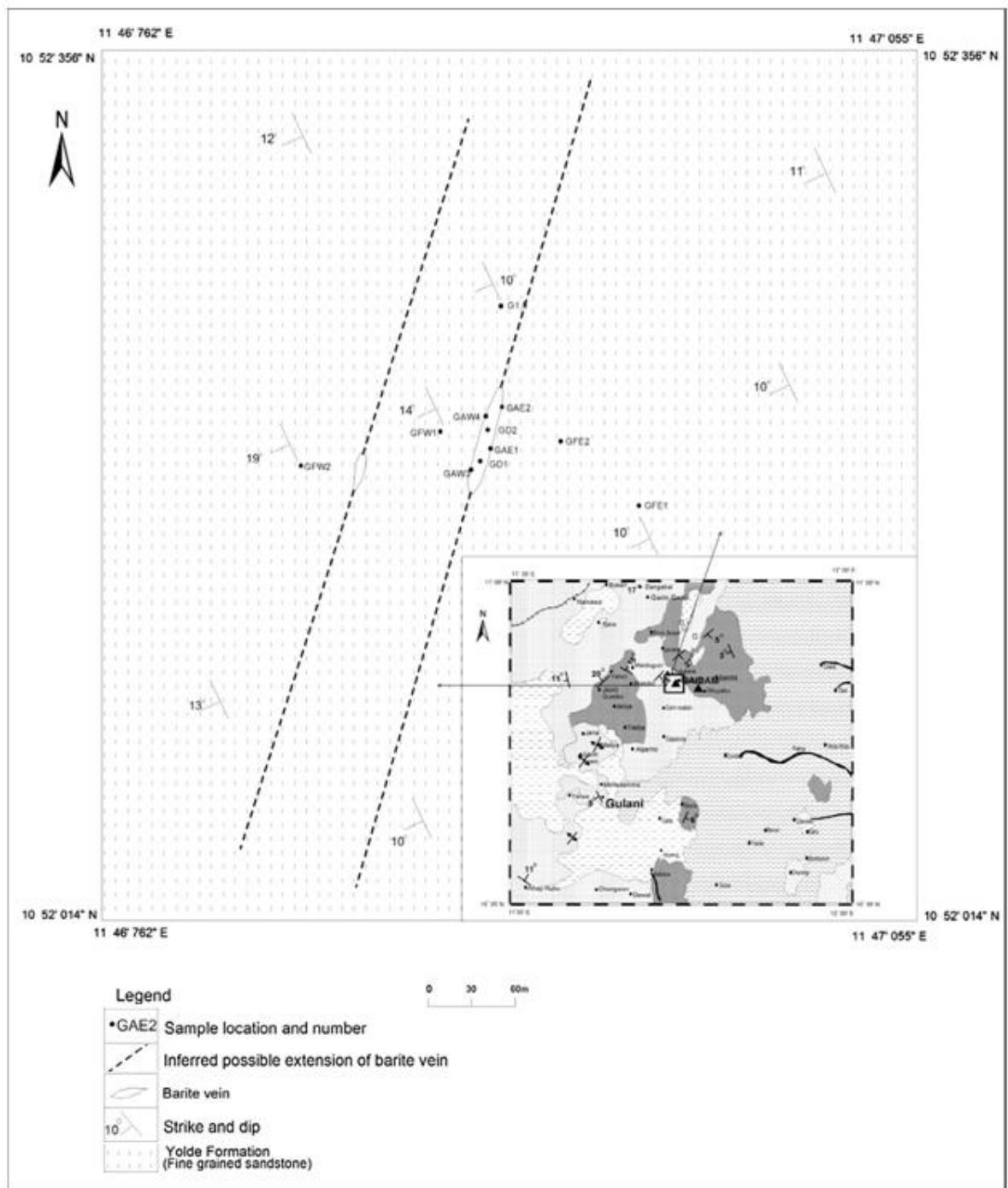

Fig. 3. Gaidam barite mineralization (GBM) area (After El-Nafaty, 2014).

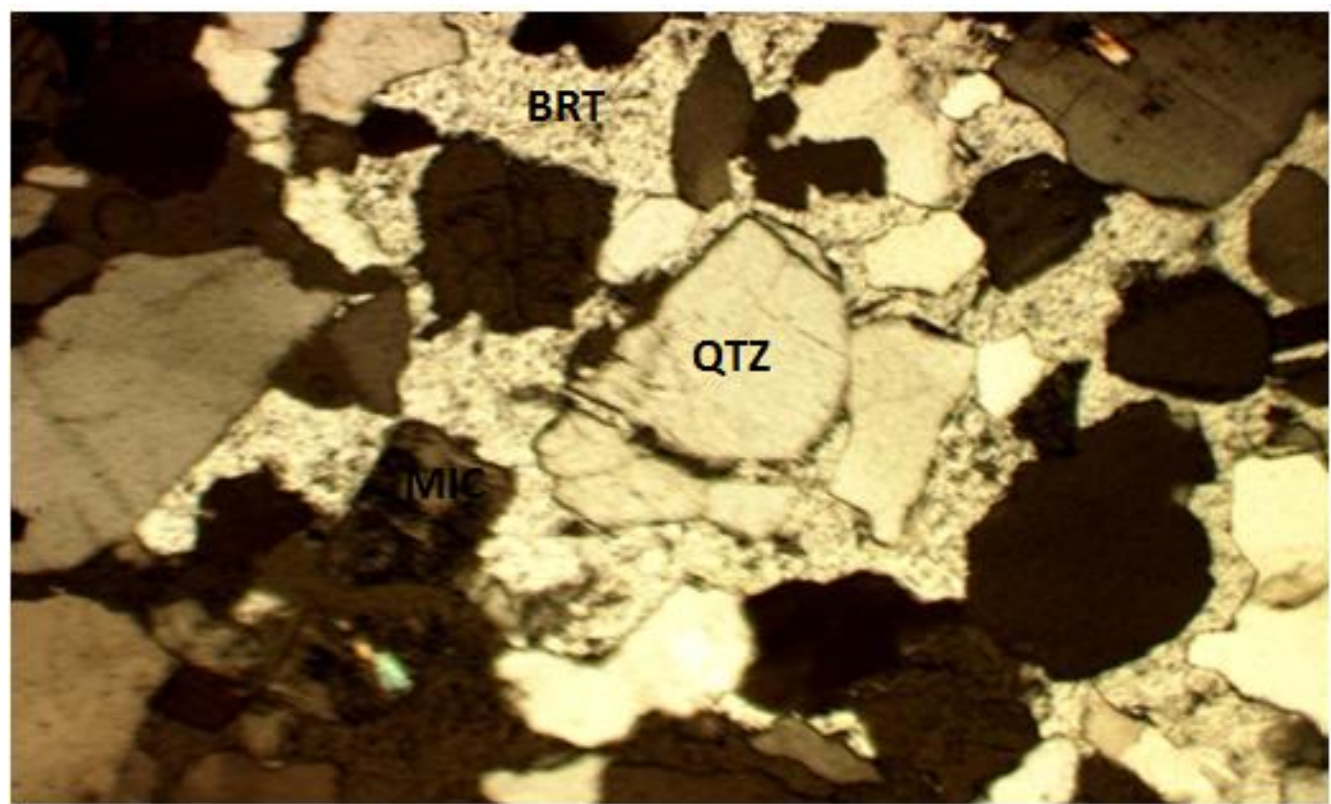

Fig. 4. Photomicrograph of altered Yolde sandstone (proximal) showing barite (BRT) filling up the pore spaces and fractures within the quartz (QTZ), crossed polars. Length of photograph $=10 \mathrm{~mm}$. 
The WBM barite occurs within medium grained Bima Sandstone. Basaltic flows cover the sandstone at the north eastern and south western corners of the mineralization area (Fig. 5). The area is similarly plain characterized by flat-lying outcrops. The single barite vein trends $340^{\circ}$ (NNW) extending for a distance of 17.2 $\mathrm{m}$ with widths varying from $3.4-3.6 \mathrm{~m}$. The vein material is similar in all aspects with that of GBM except the density which varies from $3.5-3.72 \mathrm{~g} / \mathrm{cm}^{3}$. Petrographic study of the hydrothermally altered sandstone (proximal to barite vein) is composed of quartz with barite and some microcline. The large quartz and microcline are fractured and here also the barite tends to fill the pore spaces in the sandstones and the fractures in these minerals (Fig. 6).

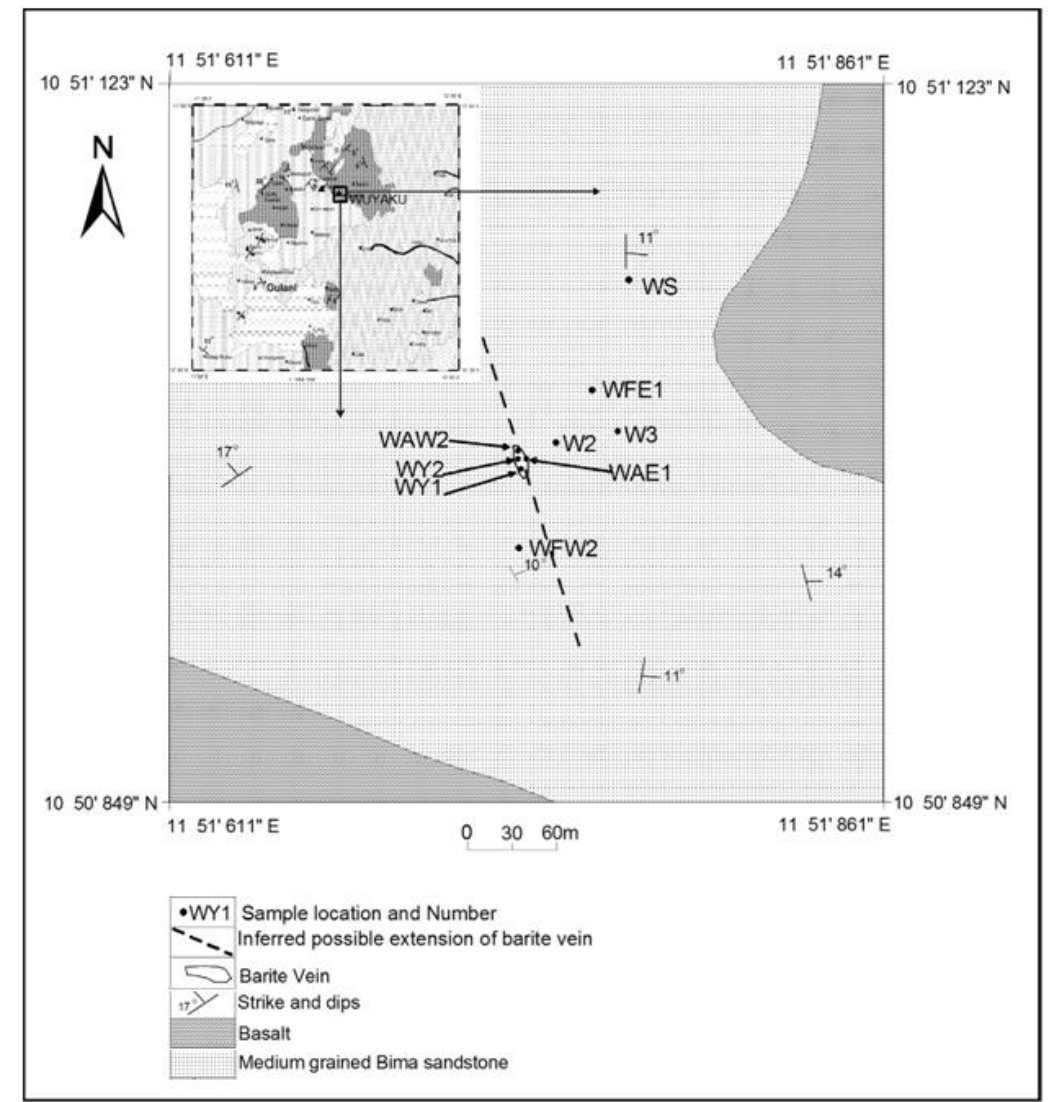

Fig. 5. Wuyaku barite mineralization (WBM) area (After El-Nafaty, 2014).

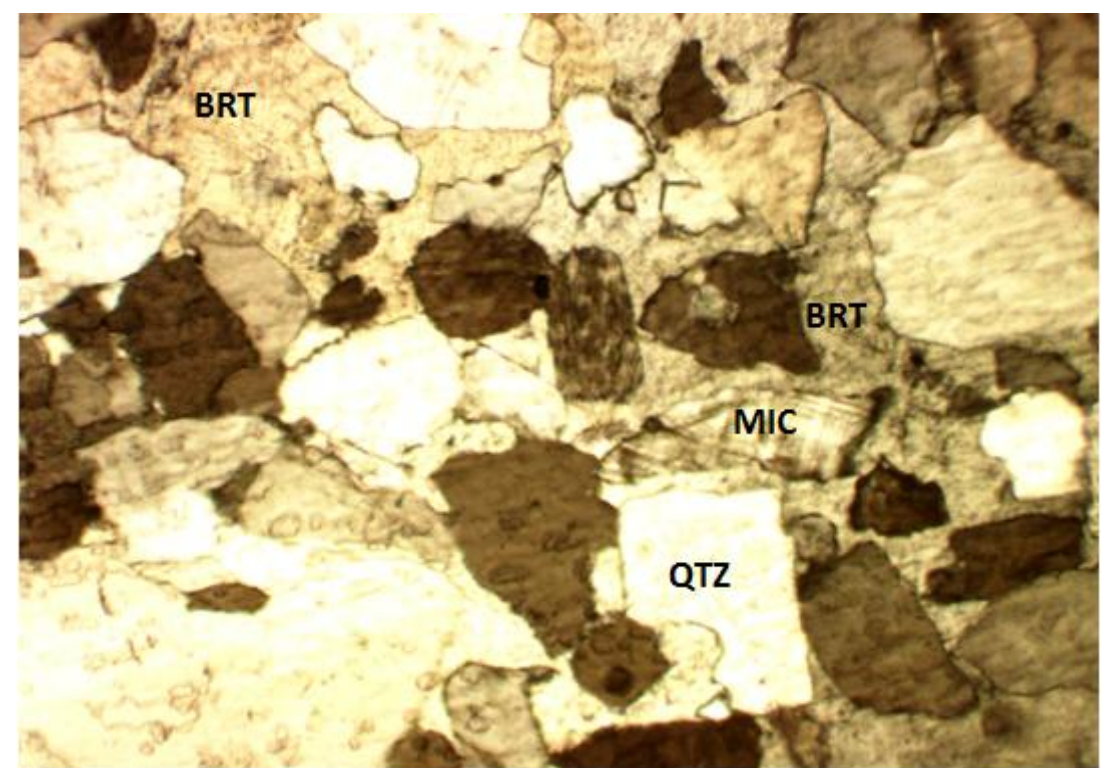

Fig. 6. Photomicrograph of altered Bima sandstone (proximal) showing barite (BRT) filling up the pore spaces, crossed polars. Length of photograph $=10 \mathrm{~mm}$. 


\subsubsection{Copper Mineralization Areas (GCM1 and GCM2)}

The geology of the area comprises of fine/medium grained granite, medium grained granite and medium grained Bima Sandstone (Fig. 7). The GCM1 is located within the fine/medium grained granite while the GCM2 is hosted by the medium grained granite. However, both occurrences are located very close to the contacts with the Bima sandstones. The mineralization zones are restricted to the highly fractured and more brittle granite side than the Bima sandstone part. The GCM1 is located within a zone having strike and dip of $011^{\circ} / 70^{\circ}$, with dip direction of $300^{\circ}$. The zone is $23 \mathrm{~m}$ long and $4.8 \mathrm{~m}$ wide. The GCM2 zone on the other hand trends $029^{\circ}$ extending for $15 \mathrm{~m}$ and having a width of $5 \mathrm{~m}$. The copper mineralization occurs as green spots of malachite within the host rock but more commonly as encrustations on the rock surfaces (Fig. 8). The green coloration of the malachite turns to grey as a result of further oxidation.

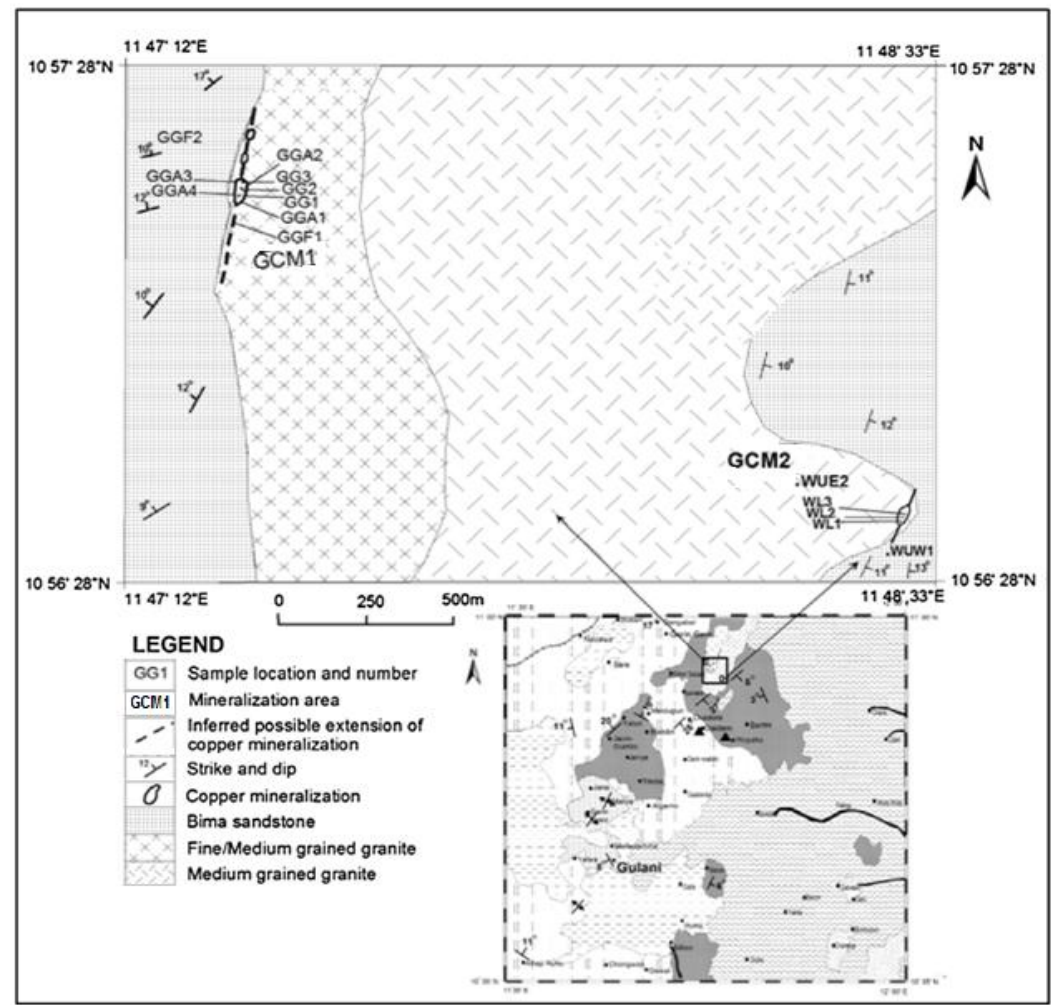

Fig. 7. Garin Gero copper mineralization (GCM1 and GCM2) areas (After El-Nafaty, 2014).

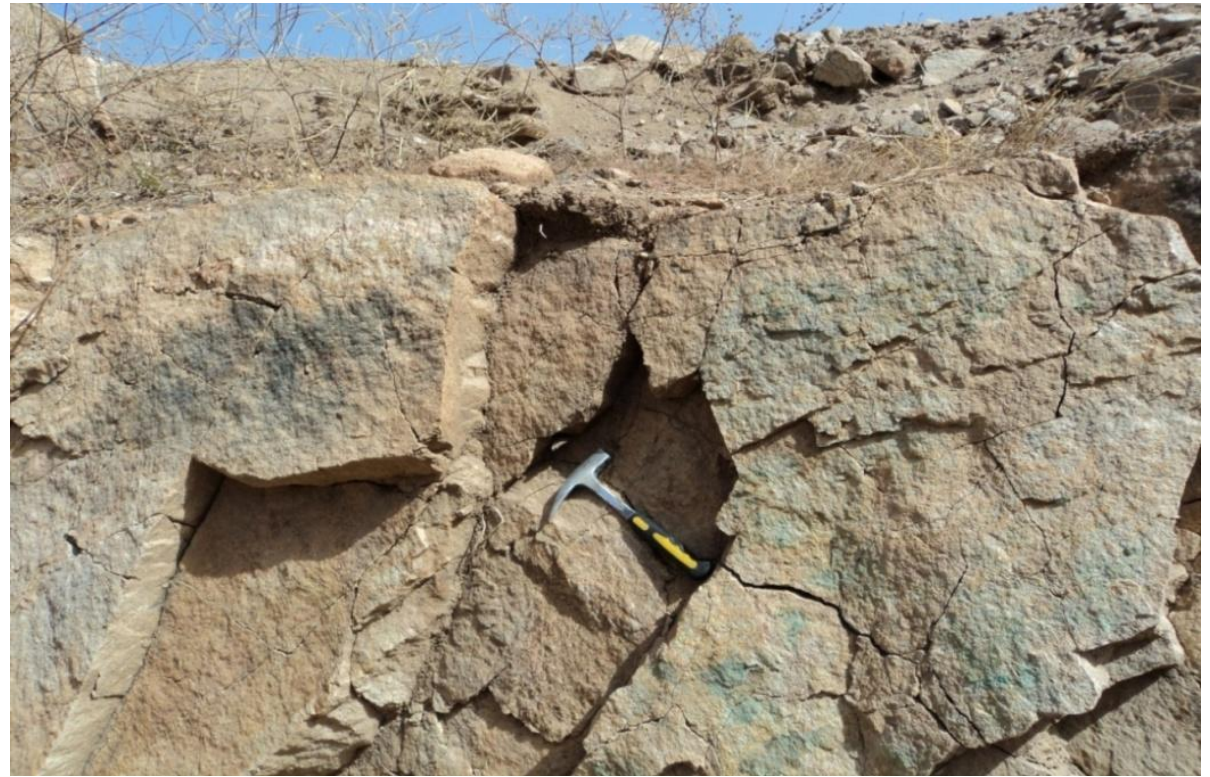

Fig. 8. Photograph of a section at the mining pit of the copper mineralized granite (GCM2) showing some encrustations of malachite (green) on the rock fracture surfaces. (N10 $0^{\circ} 56^{\prime} 726^{\prime \prime}$ and E1 $11^{\circ} 48^{\prime} 432$ '") 
Transmitted light microscopic investigation of the unaltered granites indicates the presence of quartz, microcline, plagioclase feldspar, biotite, opaques and accessory zircon. The quartz and microcline are commonly fractured as could be observed in figures 9 and 10. Reflected light microscopic study of the mineralized granites indicates the presence of chalcopyrite as the original sulphide mineral from which the malachite and limonite were transformed. The chalcopyrite now occurs as relicts or "islands" (Figs. 11 \& 12) showing varying degrees of alteration (reactive replacement) by malachite and limonite pseudomorphs. The alteration products appear as green to dark green malachite and brown to dark brown limonite as presented in figures 13 - 16. The reactive replacement is brought about by the action of acidic ground waters on the chalcopyrite veinlets or the result of rain water that was acidified as it combines or reacts with surficial organic matter and/or minerals such as pyrite during the percolation of the water into the exposed chalcopyrite veinlets. This process occurred at the leached and oxidized zones of sulphides supergene enrichment environments (Riley, 1959; Guilbert and Park Jr., 1986 and Hibbard, 2002). However, few chalcopyrite crystals also occur as disseminations in some of the silicate minerals such as feldspars and quartz.

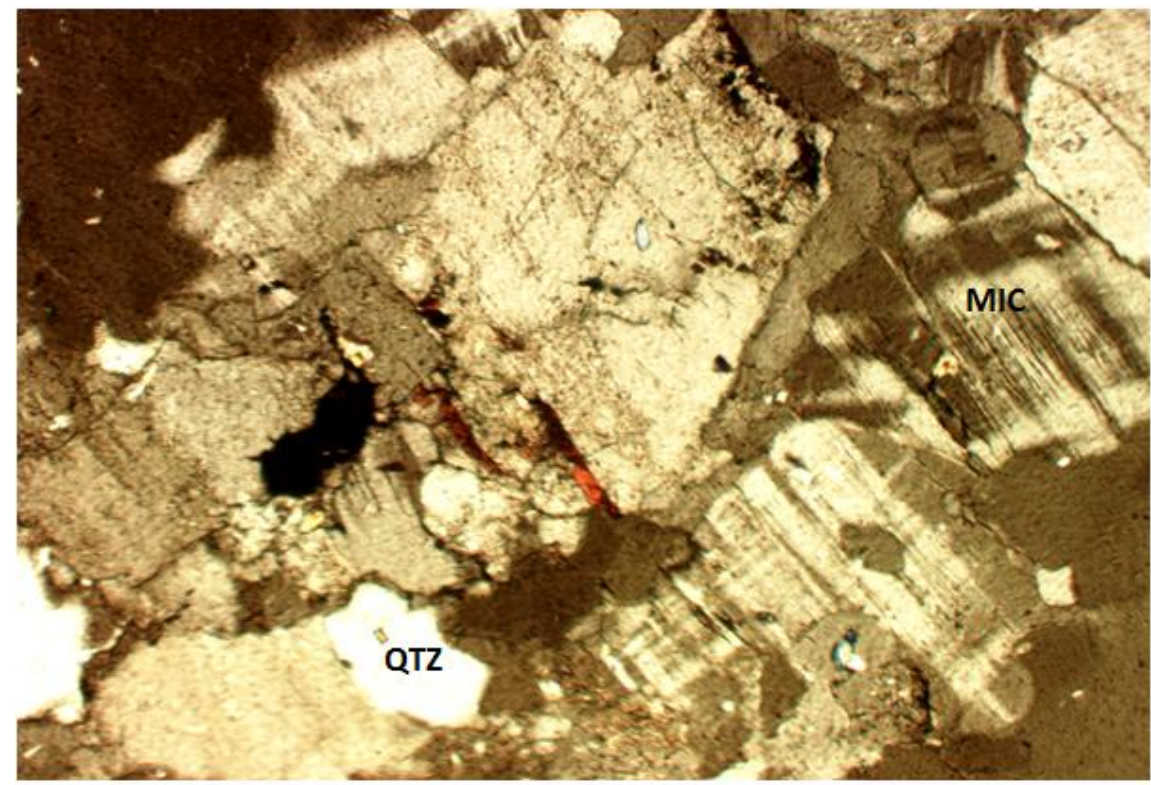

Fig. 9. photomicrograph of Fine/medium grained granite, MIC - Microcline, QTZ - Quartz and Biotite flakes, crossed polars. Length of photograph $=10 \mathrm{~mm}$. Note the fractures.

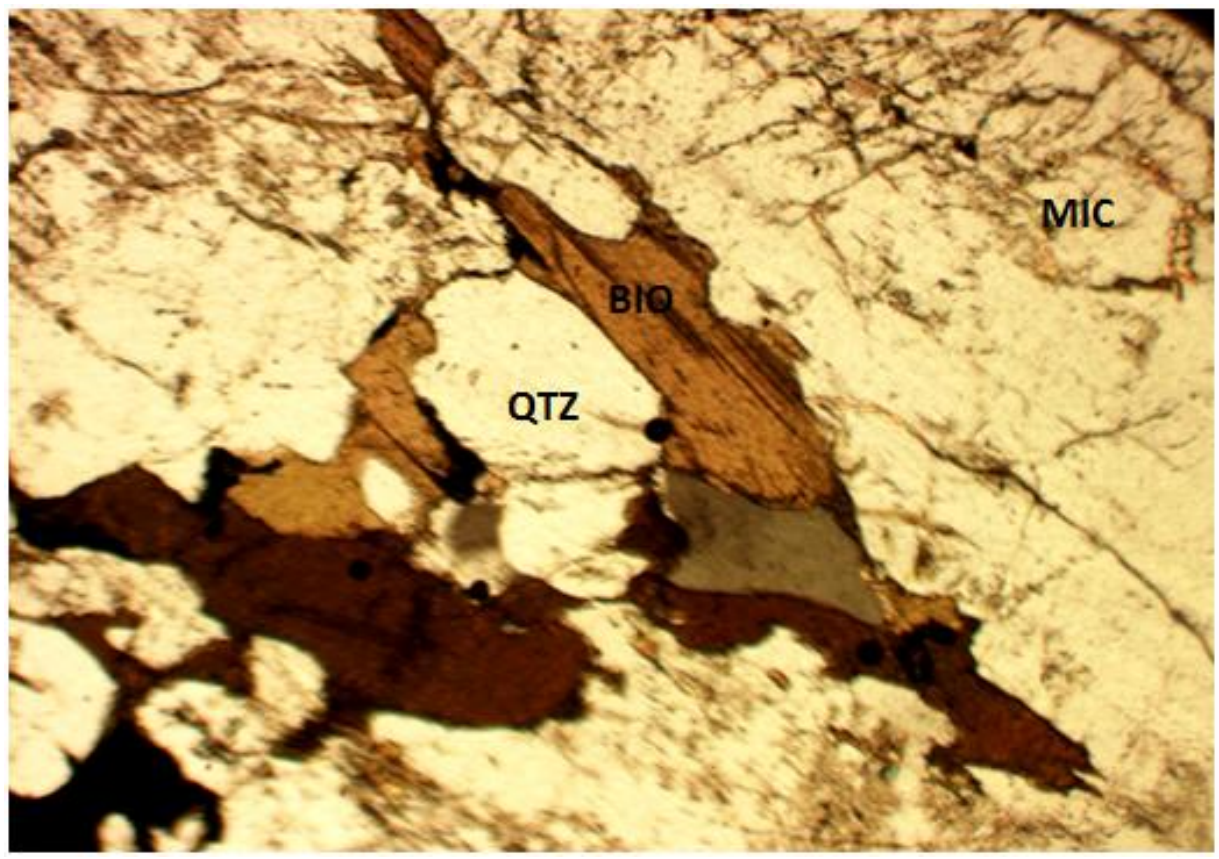

Fig. 10. photomicrograph of medium grained granite, MIC - microcline, QTZ - Quartz, BIO - Biotite, crossed polars. Length of photograph $=10 \mathrm{~mm}$. Note the fractures. 


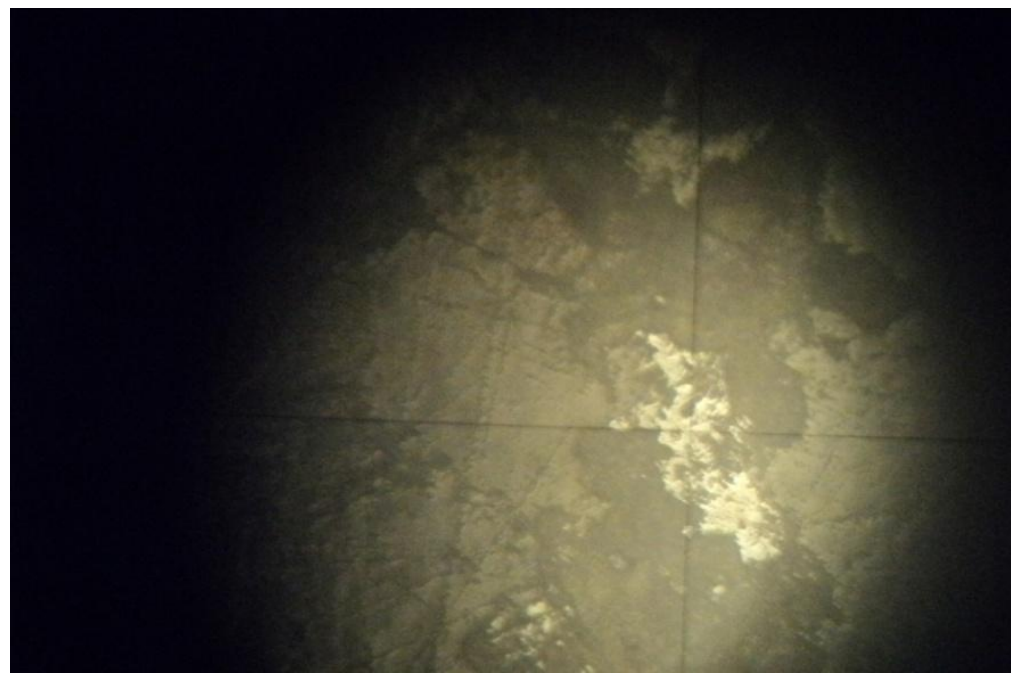

Fig. 11. Photomicrograph of relicts ("islands") of chalcopyrite in highly altered chalcopyrite veinlet in malachite mineralized granite (GCM1). $\times 100$, polished section, reflected light.

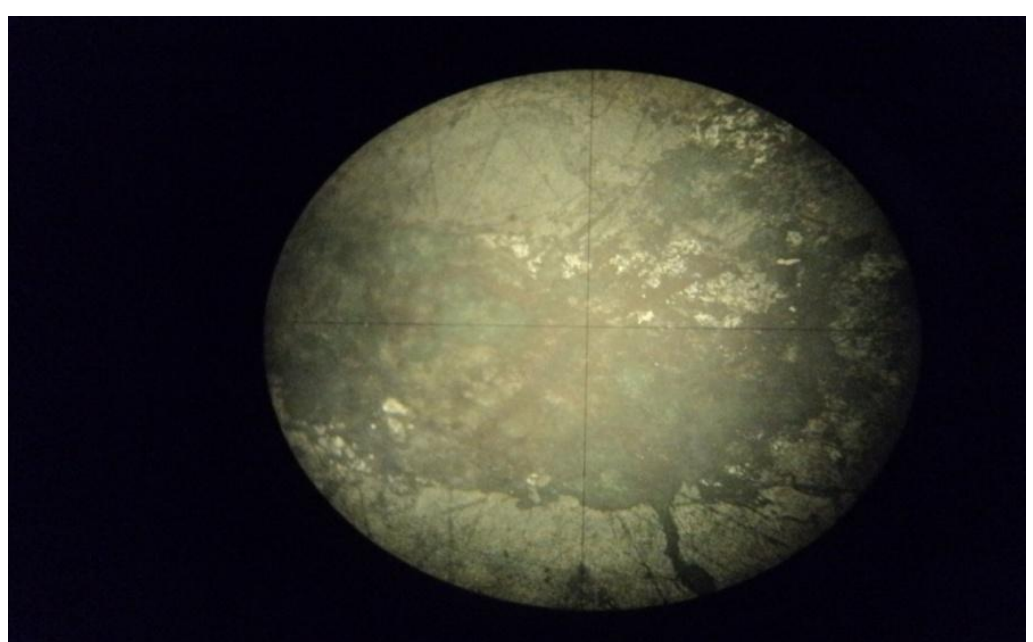

Fig. 12. Photomicrograph of relicts ("islands") of chalcopyrite in highly altered chalcopyrite veinlet in malachite mineralized granite $(\mathrm{GCM} 1) . \times 100$, polished section, reflected light.

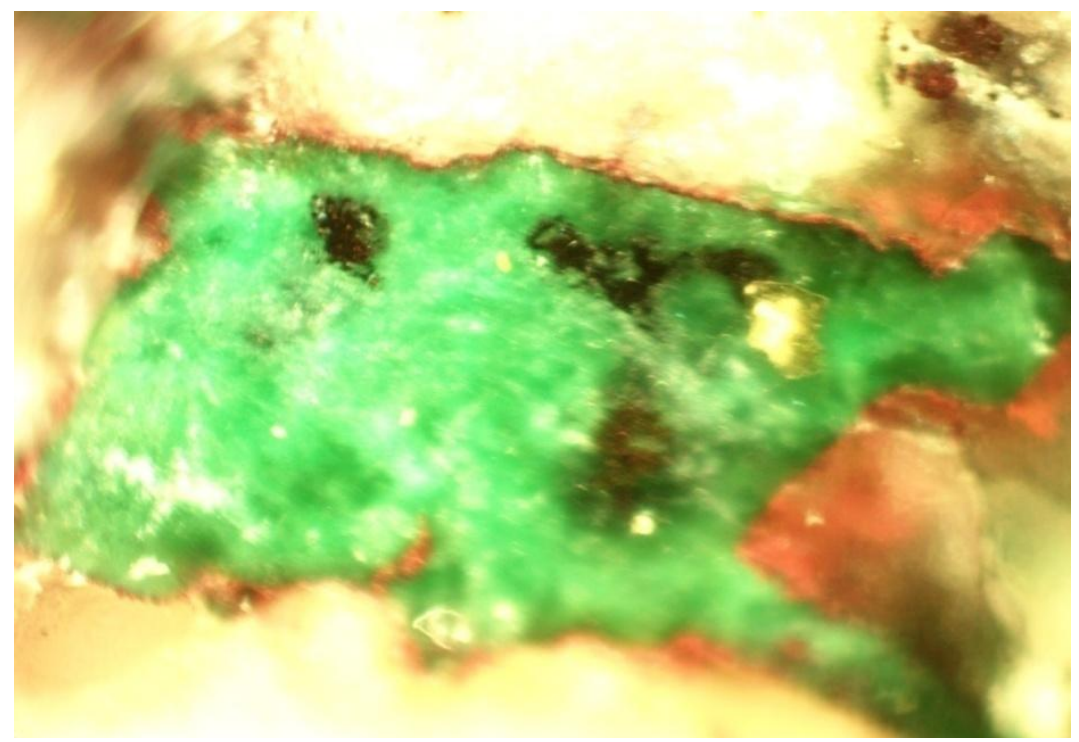

Fig. 13: Photomicrograph of chalcopyrite veinlet now represented by the alteration product of malachite (green) and limonite (brown) in malachite mineralized granite (GCM1). Polished section, reflected light, length of photograph $=10 \mathrm{~mm}$. 


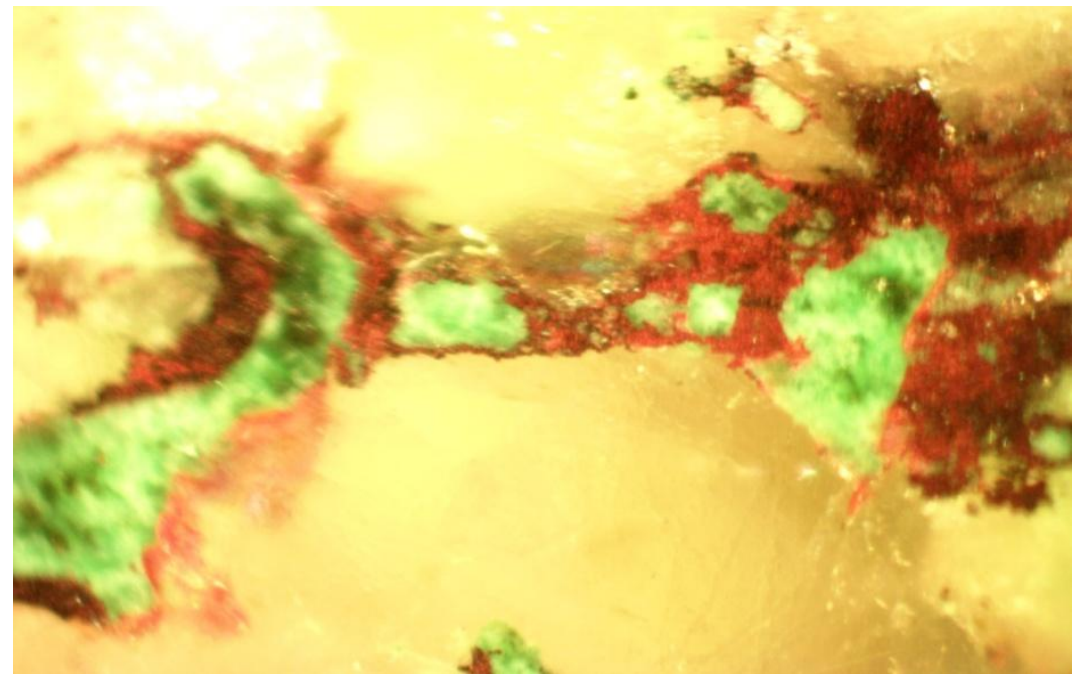

Fig. 14. Photomicrograph of veinlets showing "relicts" chalcopyrite (brass yellow) and alteration products - malachite (green) and limonite (brown) in malachite mineralized granite (GCM1), polished section, reflected light. Length of photograph $=10 \mathrm{~mm}$.

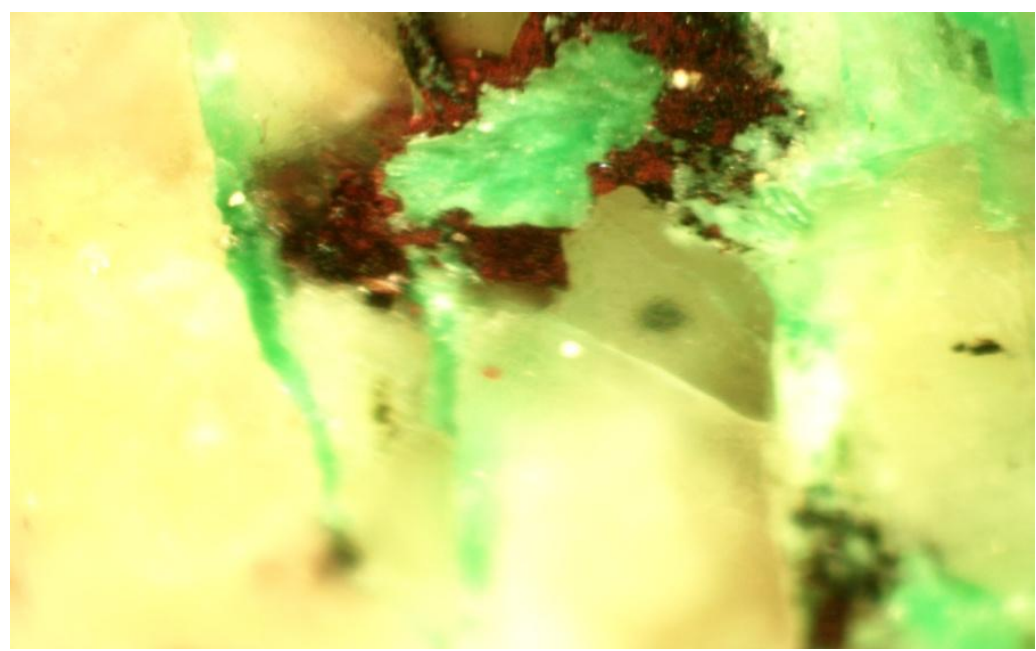

Fig. 15. Photomicrograph of "relicts" chalcopyrite (brass yellow), malachite (green) and limonite (brown) in altered chalcopyrite veinlet, in malachite mineralized granite (GCM2) Polished section, reflected light. Length of photograph $=10 \mathrm{~mm}$.

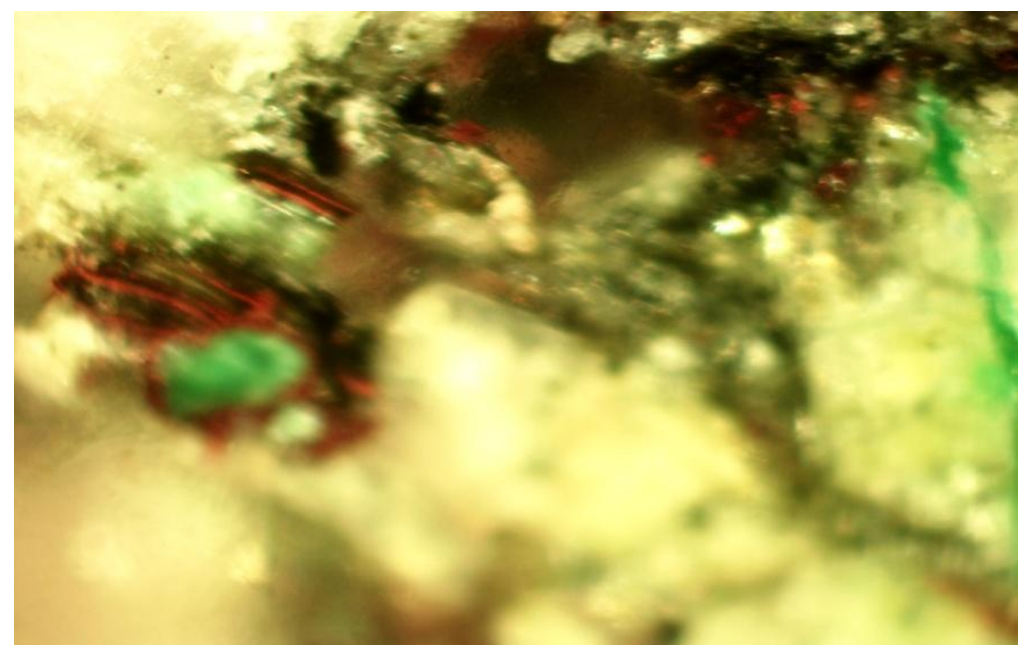

Fig. 16. Photo micrograph of "relicts" chalcopyrite (brass yellow), malachite (green) and limonite (brown) in altered chalcopyrite veinlet in malachite mineralized granite (GCM2). Polished section, reflected light. Length of photograph $=10 \mathrm{~mm}$. 
Geology and Trace Element Geochemistry of the Barite-Copper Mineralization in Gulani Area, NE

\subsection{Trace Element Geochemistry}

Geochemical analysis for trace element abundances were carried out on thirty (30) rocks and mineral separates of the four identified mineralization areas. Results of the analysis are presented in Table 1.

Table 1: Trace Element abundances of the Barite-Copper Mineralization Areas (ppm)

\begin{tabular}{|c|c|c|c|c|c|c|c|c|c|c|c|}
\hline & \multicolumn{11}{|c|}{ GAIDAM BARITE MINERALIZATION AREA (GBM) } \\
\hline & \multicolumn{4}{|c|}{ DISTAL YOLDE SANDSTONES } & \multicolumn{4}{|c|}{$\begin{array}{ll}\text { PROXIMAL } & \text { YOLDE } \\
\text { SANDSTONES } & \end{array}$} & \multicolumn{3}{|c|}{$\begin{array}{l}\text { BARITE } \\
\text { SEPARATES }\end{array}$} \\
\hline & GFE1 & GFE2 & GFW1 & GFW2 & GAE1 & GAE2 & GAW3 & GAW4 & GD1 & GD2 & \\
\hline $\mathrm{Ba}$ & $\stackrel{\infty}{2}$ & $\begin{array}{l}\vec{u} \\
\text { 心 }\end{array}$ & $\overrightarrow{\widetilde{U}}$ & Љั & $\begin{array}{l}w \\
\mathscr{\ell} \\
\mathscr{o} \\
\mathscr{\delta}\end{array}$ & 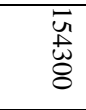 & $\begin{array}{l}\text { N } \\
\text { N }\end{array}$ & $\begin{array}{l}N \\
\infty \\
\infty \\
\infty \\
\varnothing\end{array}$ & $\begin{array}{l}v \\
\text { Ŭ } \\
\delta \\
\delta\end{array}$ & & 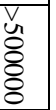 \\
\hline $\mathrm{Sr}$ & 109 & 77 & 101 & 103 & 2410 & 935 & 1660 & 1976 & 3025 & 2806 & \\
\hline $\mathrm{Rb}$ & 262 & 84 & 123 & 126 & 43 & 77 & 49 & 70 & $<2$ & $<2$ & \\
\hline $\mathrm{Sc}$ & 2 & 1 & 1 & 2 & $<1$ & $<1$ & $<1$ & $<1$ & $<1$ & $<1$ & \\
\hline $\mathrm{Be}$ & 3 & 29 & $<1$ & $<1$ & $<1$ & $<1$ & 25 & $<1$ & $<1$ & 3 & \\
\hline $\mathrm{V}$ & 16 & 11 & 12 & 11 & 7 & 10 & 5 & 10 & 6 & $<5$ & \\
\hline $\mathrm{Y}$ & 17 & 6 & 11 & 7 & 3 & 7 & 3 & 5 & $<2$ & $<2$ & \\
\hline $\mathrm{Zr}$ & 51 & 147 & 370 & 101 & 107 & 169 & 70 & 130 & 5 & $<4$ & \\
\hline $\mathrm{Cr}$ & $<20$ & $<20$ & $<20$ & $<20$ & $<20$ & $<20$ & $<20$ & $<20$ & $<20$ & $<20$ & \\
\hline Co & $<1$ & 2 & 1 & 2 & $<1$ & 1 & $<1$ & $<1$ & 1 & $<1$ & \\
\hline $\mathrm{Ni}$ & $<20$ & $<20$ & $<20$ & $<20$ & $<20$ & $<20$ & $<20$ & $<20$ & $<20$ & $<20$ & \\
\hline $\mathrm{Cu}$ & 30 & $<10$ & $<10$ & $<10$ & $<10$ & $<10$ & $<10$ & $<10$ & $<10$ & $<10$ & \\
\hline $\mathrm{Zn}$ & $<30$ & $<30$ & $<30$ & $<30$ & $<30$ & $<30$ & $<30$ & $<30$ & $<30$ & $<30$ & \\
\hline $\mathrm{Ga}$ & 18 & 6 & 7 & 8 & 3 & 4 & 2 & 4 & $<1$ & $<1$ & \\
\hline $\mathrm{Ge}$ & 2 & 1 & 1 & 1 & $<1$ & $<1$ & $<1$ & $<1$ & $<1$ & $<1$ & \\
\hline As & $<5$ & $<5$ & $<5$ & $<5$ & $<5$ & $<5$ & $<5$ & $<5$ & $<5$ & $<5$ & \\
\hline $\mathrm{Nb}$ & 235 & 7 & 12 & 85 & 5 & 591 & 5 & 5 & 149 & 3 & \\
\hline Mo & $<2$ & $<2$ & $<2$ & $<2$ & $<2$ & $<2$ & $<2$ & $<2$ & $<2$ & $<2$ & \\
\hline $\mathrm{Ag}$ & 0.5 & 1 & 2.4 & 0.8 & 0.9 & 1.3 & 0.7 & 1 & $<0.5$ & $<0.5$ & \\
\hline In & $<0.2$ & $<0.2$ & $<0.2$ & $<0.2$ & $<0.2$ & $<0.2$ & $<0.2$ & $<0.2$ & $<0.2$ & $<0.2$ & \\
\hline $\mathrm{Sn}$ & 3 & 1 & 1 & 1 & $<1$ & 2 & $<1$ & $<1$ & $<1$ & $<1$ & \\
\hline $\mathrm{Sb}$ & 0.7 & 0.6 & 1 & 0.6 & $<0.5$ & 0.9 & 0.9 & $<0.5$ & 0.6 & $<0.5$ & \\
\hline $\mathrm{Cs}$ & 7.6 & 2 & 2.2 & 2.4 & 0.6 & 1.1 & 0.6 & 0.8 & $<0.5$ & $<0.5$ & \\
\hline $\mathrm{Hf}$ & 2.4 & 3.4 & 8.8 & 2.4 & 2.9 & 4.2 & 2.2 & 3.5 & 0.9 & 0.8 & \\
\hline $\mathrm{Ta}$ & 74 & 0.7 & 1 & 25.1 & 1.1 & 196 & 1.2 & 1 & 32.3 & 1.3 & \\
\hline $\mathrm{W}$ & 4 & 6 & 3 & 3 & 2 & 9 & 5 & 2 & 8 & 2 & \\
\hline $\mathrm{Tl}$ & 1.5 & 0.5 & 0.7 & 0.7 & 0.2 & 0.4 & 0.3 & 0.4 & $<0.1$ & $<0.1$ & \\
\hline $\mathrm{Pb}$ & 34 & 12 & 19 & 19 & $<5$ & 10 & 8 & 7 & $<5$ & $<5$ & \\
\hline $\mathrm{Bi}$ & $<0.4$ & $<0.4$ & $<0.4$ & $<0.4$ & $<0.4$ & $<0.4$ & $<0.4$ & $<0.4$ & $<0.4$ & $<0.4$ & \\
\hline $\mathrm{Th}$ & 26.3 & 4.6 & 7.1 & 3.7 & 2 & 3.4 & 1.6 & 2.7 & 0.1 & $<0.1$ & \\
\hline $\mathrm{U}$ & 6.8 & 0.9 & 1.4 & 0.9 & 0.4 & 1.5 & 0.4 & 0.6 & 0.2 & $<0.1$ & \\
\hline
\end{tabular}

\begin{tabular}{|l|l|l|l|l|l|l|}
\hline \multicolumn{7}{|l|}{ WUYAKU BARITE MINERALIZATION AREA (WBM) } \\
\hline & \multicolumn{2}{|l|l|l|l|l|}{$\begin{array}{l}\text { DISTAL } \\
\text { SANDSTONES }\end{array}$} & \multicolumn{2}{l|}{$\begin{array}{l}\text { PROXIMAL } \\
\text { SANDSTONES }\end{array}$} & \multicolumn{2}{l|}{ BARITE SEPARATES } \\
\hline & WFE1 & WFW2 & WAE1 & WAW2 & WY1 & WY2 \\
\hline $\mathrm{Ba}$ & 1640 & 181200 & 482400 & 380700 & 432800 & $>500000$ \\
\hline $\mathrm{Sr}$ & 103 & 1071 & 4754 & 3288 & 3927 & 3541 \\
\hline $\mathrm{Rb}$ & 116 & 87 & 20 & 41 & 33 & $<2$ \\
\hline $\mathrm{Sc}$ & 1 & $<1$ & $<1$ & $<1$ & $<1$ & $<1$ \\
\hline $\mathrm{Be}$ & $<1$ & $<1$ & $<1$ & 4 & $<1$ & $<1$ \\
\hline $\mathrm{V}$ & 10 & 7 & 7 & 6 & 8 & 7 \\
\hline $\mathrm{Y}$ & 4 & 4 & $<2$ & $<2$ & $<2$ & $<2$ \\
\hline $\mathrm{Zr}$ & 86 & 48 & 9 & 30 & 21 & $<4$ \\
\hline $\mathrm{Cr}$ & $<20$ & $<20$ & $<20$ & $<20$ & $<20$ & $<20$ \\
\hline $\mathrm{Co}$ & 2 & $<1$ & $<1$ & $<1$ & 9 & $<1$ \\
\hline $\mathrm{Ni}$ & $<20$ & $<20$ & $<20$ & $<20$ & $<20$ & $<20$ \\
\hline $\mathrm{Cu}$ & $<10$ & $<10$ & $<10$ & $<10$ & $<10$ & $<10$ \\
\hline $\mathrm{Zn}$ & $<30$ & $<30$ & $<30$ & $<30$ & $<30$ & $<30$ \\
\hline $\mathrm{Ga}$ & 7 & 5 & 1 & 2 & 2 & $<1$ \\
\hline $\mathrm{Ge}$ & 1 & $<1$ & $<1$ & $<1$ & $<1$ & $<1$ \\
\hline $\mathrm{As}$ & $<5$ & $<5$ & $<5$ & $<5$ & $<5$ & $<5$ \\
\hline $\mathrm{Nb}$ & 5 & 31 & 2 & 2 & 26 & 1 \\
\hline $\mathrm{Mo}$ & $<2$ & $<2$ & $<2$ & $<2$ & $<2$ & $<2$ \\
\hline $\mathrm{Ag}$ & 0.6 & $<0.5$ & $<0.5$ & $<0.5$ & $<0.5$ & $<0.5$ \\
\hline $\mathrm{In}$ & $<0.2$ & $<0.2$ & $<0.2$ & $<0.2$ & $<0.2$ & $<0.2$ \\
\hline $\mathrm{Sn}$ & $<1$ & $<1$ & $<1$ & $<1$ & $<1$ & $<1$ \\
\hline $\mathrm{Sb}$ & $<0.5$ & $<0.5$ & $<0.5$ & $<0.5$ & $<0.5$ & $<0.5$ \\
\hline
\end{tabular}


Geology and Trace Element Geochemistry of the Barite-Copper Mineralization in Gulani Area, NE

\begin{tabular}{|l|l|l|l|l|l|l|}
\hline $\mathrm{Cs}$ & 1.3 & 0.8 & $<0.5$ & 0.6 & 0.5 & $<0.5$ \\
\hline $\mathrm{Hf}$ & 21 & 1.5 & 0.9 & 1.3 & 1.2 & 0.8 \\
\hline $\mathrm{Ta}$ & 0.5 & 8.9 & 1 & 0.9 & 8.4 & 1.2 \\
\hline $\mathrm{W}$ & 2 & 2 & 2 & 1 & 52 & 2 \\
\hline $\mathrm{Tl}$ & 0.6 & 0.5 & 0.1 & 2 & 0.2 & $<0.1$ \\
\hline $\mathrm{Pb}$ & 23 & 17 & $<5$ & 0.2 & $<5$ & $<5$ \\
\hline $\mathrm{Bi}$ & $<0.4$ & $<0.4$ & $<0.4$ & $<0.4$ & $<0.4$ & $<0.4$ \\
\hline $\mathrm{Th}$ & 3.9 & 2.8 & 0.8 & 1.2 & 1.6 & $<0.1$ \\
\hline $\mathrm{U}$ & 0.8 & 0.8 & 0.2 & 0.5 & 0.4 & $<0.1$ \\
\hline
\end{tabular}

\begin{tabular}{|c|c|c|c|c|c|c|c|c|c|}
\hline & \multicolumn{9}{|c|}{ GARIN GERO COPPER MINERALIZATION AREA 1 (GCM 1) } \\
\hline & \multicolumn{2}{|c|}{ DISTAL } & \multirow{2}{*}{\multicolumn{4}{|c|}{ PROXIMAL GRANITES }} & \multirow{2}{*}{\multicolumn{3}{|c|}{ MINERALIZED GRANITES }} \\
\hline & GRANITE & $\begin{array}{l}\text { BIMA } \\
\text { SANDSTONE }\end{array}$ & & & & & & & \\
\hline & GGF1 & GGF2 & GGA1 & GGA2 & GGA3 & GGA4 & GG1 & GG2 & GG3 \\
\hline $\mathrm{Cu}$ & 20 & 100 & 1370 & 2650 & 1700 & 7140 & $>10000$ & $>10000$ & $>10000$ \\
\hline $\mathrm{Ba}$ & 1218 & 1292 & 676 & 810 & 684 & 950 & 856 & 496 & 384 \\
\hline $\mathrm{Sr}$ & 99 & 137 & 189 & 159 & 184 & 185 & 159 & 145 & 150 \\
\hline $\mathrm{Rb}$ & 131 & 121 & 112 & 102 & 73 & 133 & 83 & 48 & 52 \\
\hline $\mathrm{Ag}$ & 3.3 & 1.9 & 3.8 & 4.1 & 8.7 & 3 & 6.5 & 12.5 & 15.6 \\
\hline $\mathrm{U}$ & 1.6 & 1.8 & 2.2 & 6.5 & 9.1 & 2.4 & 9.3 & 19.1 & 16.6 \\
\hline $\mathrm{V}$ & 15 & 20 & 105 & 194 & 214 & 223 & 372 & 331 & 430 \\
\hline $\mathrm{Zr}$ & 488 & 221 & 304 & 469 & 1285 & 225 & 545 & 1039 & 592 \\
\hline $\mathrm{Y}$ & 15 & 6 & 14 & 17 & 89 & 11 & 15 & 60 & 23 \\
\hline $\mathrm{Sc}$ & 2 & 2 & 4 & 3 & 8 & 2 & 4 & 8 & 9 \\
\hline $\mathrm{Be}$ & $<1$ & 1 & 2 & 2 & 2 & 2 & 2 & 2 & 3 \\
\hline $\mathrm{Cr}$ & $<20$ & $<20$ & $<20$ & $<20$ & $<20$ & $<20$ & $<20$ & $<20$ & $<20$ \\
\hline $\mathrm{Co}$ & 2 & 2 & 2 & 2 & 3 & 1 & 2 & 2 & 30 \\
\hline $\mathrm{Ni}$ & $<20$ & $<20$ & $<20$ & $<20$ & $<20$ & $<20$ & $<20$ & $<20$ & $<20$ \\
\hline $\mathrm{Zn}$ & $<30$ & $<30$ & 50 & 30 & 70 & $<30$ & 30 & 60 & 80 \\
\hline $\mathrm{Ga}$ & 9 & 11 & 16 & 15 & 21 & 13 & 15 & 16 & 16 \\
\hline $\mathrm{Ge}$ & 1 & 1 & 1 & 1 & 2 & 1 & 1 & 2 & 2 \\
\hline As & $<5$ & $<5$ & $<5$ & $<5$ & $<5$ & $<5$ & $<5$ & $<5$ & $<5$ \\
\hline $\mathrm{Nb}$ & 14 & 7 & 6 & 10 & 62 & 3 & 14 & 54 & 33 \\
\hline Mo & $<2$ & $<2$ & $<2$ & $<2$ & $<2$ & $<2$ & $<2$ & $<2$ & $<2$ \\
\hline In & $<0.2$ & $<0.2$ & $<0.2$ & $<, 0.2$ & $<0.2$ & $<0.2$ & $<0.2$ & $<0.2$ & $<0.2$ \\
\hline $\mathrm{Sn}$ & 1 & 1 & 2 & 3 & 4 & 1 & 3 & 5 & 4 \\
\hline $\mathrm{Sb}$ & 0.6 & $<0.5$ & 0.6 & 0.6 & 0.5 & 0.5 & 0.5 & 0.6 & 0.6 \\
\hline $\mathrm{Cs}$ & 2.9 & 1.5 & 3.8 & 1.5 & 1.1 & 3.7 & 1.4 & 1.4 & 1.7 \\
\hline $\mathrm{Ta}$ & 1.1 & 0.7 & 0.3 & 0.4 & 2.7 & 0.2 & 0.5 & 2.9 & 1.6 \\
\hline $\mathrm{Hf}$ & 11 & 5 & 7.3 & 10.6 & 29.8 & 5.3 & 12.1 & 24.3 & 13.4 \\
\hline W & 2 & 1 & 2 & 2 & 2 & 1 & 2 & 2 & 2 \\
\hline $\mathrm{Tl}$ & 0.8 & 0.7 & 0.6 & 0.5 & 0.4 & 0.7 & 0.4 & 0.3 & 0.3 \\
\hline $\mathrm{Pb}$ & 21 & 21 & 24 & 25 & 24 & 26 & 24 & 18 & 16 \\
\hline $\mathrm{Bi}$ & $<0.4$ & $<0.4$ & $<0.4$ & $<0.4$ & $<0.4$ & $<0.4$ & 0.5 & 0.4 & 0.4 \\
\hline Th & 8.2 & 9.2 & 18.5 & 15.9 & 24.1 & 11 & 11.9 & 26.4 & 18.5 \\
\hline
\end{tabular}

\begin{tabular}{|c|c|c|c|c|c|}
\hline \multicolumn{6}{|c|}{ GARIN GERO COPPER MINERALIZATION AREA 2 (GCM 2) } \\
\hline & \multicolumn{2}{|c|}{ Distal } & \multirow{2}{*}{\multicolumn{2}{|c|}{$\begin{array}{l}\text { MINERALIZED } \\
\text { GRANITES }\end{array}$}} & \multirow{3}{*}{$\begin{array}{l}\text { MALCHITE } \\
\text { SEPARATE } \\
\text { WL1 }\end{array}$} \\
\hline & BIMA SANDSTONE & GRANITE & & & \\
\hline & WUW1 & WUE2 & WL2 & WL3 & \\
\hline $\mathrm{Cu}$ & 260 & 1180 & $>10000$ & $>10000$ & $>10000$ \\
\hline $\mathrm{Ba}$ & 768 & 1040 & 747 & 1390 & 677 \\
\hline $\mathrm{Sr}$ & 137 & 497 & 292 & 348 & 162 \\
\hline $\mathrm{Rb}$ & 122 & 127 & 78 & 79 & 65 \\
\hline $\mathrm{Ag}$ & 9.6 & 11.7 & $>100$ & $>100$ & $>100$ \\
\hline $\mathrm{U}$ & 1.3 & 3.7 & 14.3 & 29.2 & 70.8 \\
\hline $\mathrm{Pb}$ & 21 & 46 & 109 & 547 & 9960 \\
\hline $\mathrm{V}$ & 17 & 37 & 70 & 73 & 834 \\
\hline $\mathrm{Y}$ & 5 & 11 & 11 & 14 & 23 \\
\hline $\mathrm{Sc}$ & 1 & 4 & 3 & 4 & 8 \\
\hline $\mathrm{Be}$ & 1 & 4 & 2 & 3 & 3 \\
\hline $\mathrm{Zr}$ & 81 & 127 & 232 & 76 & 64 \\
\hline $\mathrm{Cr}$ & $<20$ & $<20$ & $<20$ & $<20$ & $<20$ \\
\hline $\mathrm{Co}$ & 3 & 4 & 2 & 3 & 2 \\
\hline $\mathrm{Ni}$ & $<20$ & $<20$ & $<20$ & $<20$ & $<20$ \\
\hline $\mathrm{Zn}$ & $<30$ & 40 & $<30$ & $<30$ & 40 \\
\hline $\mathrm{Ga}$ & 10 & 19 & 13 & 13 & 10 \\
\hline $\mathrm{Ge}$ & 1 & 1 & 1 & 1 & $<1$ \\
\hline As & $<5$ & $<5$ & $<5$ & $<5$ & $<5$ \\
\hline
\end{tabular}




\begin{tabular}{|l|l|l|l|l|l|}
\hline $\mathrm{Nb}$ & 5 & 9 & 8 & 5 & 5 \\
\hline $\mathrm{Mo}$ & $<2$ & $<2$ & $<2$ & $<2$ & 5 \\
\hline $\mathrm{In}$ & $<0.2$ & $<0.2$ & $<0.2$ & $<0.2$ & $<0.2$ \\
\hline $\mathrm{Sn}$ & 1 & 3 & 2 & 2 & 2 \\
\hline $\mathrm{Sb}$ & $<0.5$ & $<0.5$ & 0.6 & 0.6 & 0.6 \\
\hline $\mathrm{Cs}$ & 2.7 & 5 & 2.3 & 1.9 & 2.3 \\
\hline $\mathrm{Ta}$ & 0.5 & 0.9 & 0.7 & 0.5 & 0.5 \\
\hline $\mathrm{Hf}$ & 2 & 3.5 & 5.7 & 2.1 & 1.7 \\
\hline $\mathrm{W}$ & 2 & $<1$ & 1 & 4 & 2 \\
\hline $\mathrm{Tl}$ & 0.7 & 0.7 & 0.5 & 0.5 & 0.4 \\
\hline $\mathrm{Bi}$ & $<0.4$ & $<0.4$ & 1.3 & 6.7 & 16 \\
\hline $\mathrm{Th}$ & 7.9 & 9.5 & 9.2 & 5.5 & 7 \\
\hline
\end{tabular}

\subsubsection{Barite Mineralization Areas}

The most important trace elements in these mineralization areas are $\mathrm{Ba}, \mathrm{Sr}$ and $\mathrm{Rb}$. The three elements show similar trends in both GBM and WBM. In GBM, Ba content varies from $866-1968$ ppm with an average of $1536 \mathrm{ppm}(\mathrm{n}=4)$ in the distal sandstones; $154,300-399500 \mathrm{ppm}$ averaging $283675 \mathrm{ppm}(\mathrm{n}=4)$ in the proximal sandstones to $>500,000 \mathrm{ppm}(>50 \mathrm{wt} \%)$ in the barite vein. There is marked increase in Ba values from the distal (unaltered) sandstones through the proximal (hydrothermally altered) sandstones to the barite vein which is essentially pure $\mathrm{BaSO}_{4}$. The average crustal value of $\mathrm{Ba}$ is $425 \mathrm{ppm}$. Strontium ( $\mathrm{Sr}$ ) abundance follows relatively a similar trend to that of Ba in GBM. It varies from $77-109 \mathrm{ppm}$ with an average of $98 \mathrm{ppm}$ in the distal sandstones through $935-2410 \mathrm{ppm}$ having an average of $1745 \mathrm{ppm}$ in the proximal sandstones to 2806 $3025 \mathrm{ppm}$ with an average of $2916 \mathrm{ppm}$ in barite vein. There is a general positive correlation between Ba and $\mathrm{Sr}$. The average crustal value of $\mathrm{Sr}$ is $375 \mathrm{ppm}$ (Mason, 1966). Rb abundances vary from 84-123 ppm with an average value of $149 \mathrm{ppm}$ in the distal sandstone, these values diminish to a range of 43-77 ppm with an average of $60 \mathrm{ppm}$ in the proximal sandstones. The value is further diminished to an average of $<2 \mathrm{ppm}$ in the barite vein. The average crustal value of $\mathrm{Rb}$ is $90 \mathrm{ppm}$.

On the other hand Ba concentration in WBM varies from $1640-181200 \mathrm{ppm}$, having an average of $91420 \mathrm{ppm}(\mathrm{n}=2)$ in the distal sandstones. The values increase to a range of $380700-482400 \mathrm{ppm}$ averaging $431100 \mathrm{ppm}(\mathrm{n}=2)$ in the proximal sandstones and further enriched to $432,800->500000 \mathrm{ppm}$ in the barite veins. Strontium on the other hand in WBM range from $103-1071 \mathrm{ppm}$ (average $587 \mathrm{ppm}$ ) in distal sandstones; 3288 - $4754 \mathrm{ppm}$ (average $4021 \mathrm{ppm}$ ) in proximal sandstones to 3541 - $3927 \mathrm{ppm}$ with an average of $3734 \mathrm{ppm}$ in barite separates. A positive correlation is here also shown between $\mathrm{Ba}$ and $\mathrm{Sr}$ which indicates close association of the two elements in the barite mineralizing solutions (Table 1). Rubidium shows decreasing trend similar to that of GBM and ranges from $87-116 \mathrm{ppm}$ (average $102 \mathrm{ppm}$ ) in distal sandstones; $20-41$ ppm (average $31 \mathrm{ppm}$ ) in the proximal sandstones with further decrease to $<2-33 \mathrm{ppm}$ (average $17.5 \mathrm{ppm}$ ) in barite vein. The average crustal value of $\mathrm{Rb}$ is $90 \mathrm{ppm}$; therefore depletion of the element is noticeable in the proximal sandstones probably as a result of leaching by the invading hydrothermal solutions in the sandstones.

\subsubsection{Copper Mineralization Areas}

Here also, in addition to the three important elements of $\mathrm{Ba}, \mathrm{Sr}$ and $\mathrm{Rb}, \mathrm{Cu}$ occurs in anomalous values. Other significant elements in this areas include $\mathrm{Ag}, \mathrm{U}, \mathrm{V}, \mathrm{Zr} \mathrm{Pb}$ and $\mathrm{Y}$. Copper shows high enrichment in proximal granites with values varying from $1370 \mathrm{ppm}-7140 \mathrm{ppm}$ (GCM1) to amounts $>10,000 \mathrm{ppm}(1 \% \mathrm{Cu})$ in the copper mineralized granites and malachite/chalcopyrite separate. The high $\mathrm{Cu}$ concentration here is above the upper detection limit of the ICP/MS indicating higher than $1 \% \mathrm{Cu}$ values. The average copper content of unaltered granite is $13 \mathrm{ppm}$ (Mason, 1966).

In the GCM1, the Ba concentration decreases remarkably in value from the distal granite through the proximal granites to malachite mineralized granites. The values vary from $1218 \mathrm{ppm}$ in distal granite; 676 - 950 ppm (average of $780 \mathrm{ppm})(\mathrm{n}=4)$ in the proximal granites and $384-856 \mathrm{ppm}$ (average of $579 \mathrm{ppm})(\mathrm{n}=3)$ in the malachite mineralized granites. This pattern is in contrast to the trends in the barite mineralization areas (Table 1). Sr varies from $99 \mathrm{ppm}$ in distal granite through 159 - $189 \mathrm{ppm}$ (averaging $179 \mathrm{ppm}$ ) in the proximal granites to a range of $145-159 \mathrm{ppm}$ (average of $151 \mathrm{ppm}$ ) in the $\mathrm{Cu}$ mineralized granites. Sr therefore, decreases from the proximal to mineralized granite. $\mathrm{Rb}$ concentration follows a similar trend to that of the $\mathrm{Ba}$ in these samples with the $\mathrm{Rb}$ value of $131 \mathrm{ppm}$ in the distal granite. In the proximal granites $\mathrm{Rb}$ ranges from 73 $133 \mathrm{ppm}$ with an average of $105 \mathrm{ppm}$ while in the malachite mineralized granites, the range is $48-83 \mathrm{ppm}$ (average of $61 \mathrm{ppm}$ ). There is a general depletion of $\mathrm{Ba}, \mathrm{Sr}$ and $\mathrm{Rb}$ which can be explained to leaching related to the hydrothermal solutions.

Ag content in the distal granite is $3 \mathrm{ppm}$ and increases to a range of $3-8.7 \mathrm{ppm}$ with an average of 4.9 $\operatorname{ppm}(\mathrm{n}=4)$ in the proximal granites and the value is further enriched to a range of $6.5-15.6 \mathrm{ppm}$ averaging $11.5 \mathrm{ppm}(\mathrm{n}=3)$ in the mineralized granites. Mason (1966) gave an average value of $0.04 \mathrm{ppm}$ of $\mathrm{Ag}$ in granite; therefore, the Ag abundances indicate enrichment of the element. Uranium value in the distal granite is $1.6 \mathrm{ppm}$ 
which increases in the proximal granites to a range of $2.2-9.1 \mathrm{ppm}$ with an average of $5.04 \mathrm{ppm}$. This is further increased to values ranging from $9.3-19.1 \mathrm{ppm}$ averaging $15 \mathrm{ppm}$ in mineralized granites. The average value of $\mathrm{U}$ content in granite is $3.7 \mathrm{ppm}$ (Mason, 1966). Recorded V value in the distal granite is $15 \mathrm{ppm}$, this is enriched to a range of $105-223 \mathrm{ppm}$ with an average of $184 \mathrm{ppm}$ in the proximal granites, and this is again enriched to a range of $331-430 \mathrm{ppm}$ averaging $378 \mathrm{ppm}$ in the mineralized granites. The average value of $\mathrm{V}$ in granite is given as $16 \mathrm{ppm}$. $\mathrm{Zr}$ having a standard value of $210 \mathrm{ppm}$ in granite is enriched from $488 \mathrm{ppm}$ in the distal granite to a range of $225-1285 \mathrm{ppm}$ with an average of $551 \mathrm{ppm}$ in the proximal granites which is further increased to a range of $545-1039 \mathrm{ppm}$ averaging $725 \mathrm{ppm}$ in the enriched granites. Y abundance in the distal granite is $15 \mathrm{ppm}$ which increases to a range of $11-89 \mathrm{ppm}$ with an average of $33 \mathrm{ppm}$ in the proximal granite. The range in the mineralized granite is $15-60 \mathrm{ppm}$ giving an average of $33 \mathrm{ppm}$. Standard value of $\mathrm{Y}$ in granite is $13 \mathrm{ppm}$.

In the GCM2, Ba concentration is $1040 \mathrm{ppm}$ in the distal granite whereas the malachite mineralized granites have values of $747-1390 \mathrm{ppm}$ with an average of $1069 \mathrm{ppm}(\mathrm{n}=2)$. The malachite/chalcopyrite separate has a relative lower value of $677 \mathrm{ppm}$. The Ba concentration is diminished from the mineralized granites to the malachite/chalcopyrite separate. Sr on the other hand diminishes in abundance from $497 \mathrm{ppm}$ in the distal granite to a range of $292-348 \mathrm{ppm}$ averaging $320 \mathrm{ppm}$ in the malachite mineralized granites to a lower value of $162 \mathrm{ppm}$ in the malachite/chalcopyrite separate. Rb shows a similar pattern to that of $\mathrm{Sr}$ indicating a decreasing value from the distal granite having $127 \mathrm{ppm}$ while the malachite mineralized granites have values of $78-79 \mathrm{ppm}$ averaging $78.5 \mathrm{ppm}$, the value further decreases to $65 \mathrm{ppm}$ in the malachite/chalcopyrite separate. Therefore, $\mathrm{Sr}$ and $\mathrm{Rb}$ have negative correlation with $\mathrm{Cu}$ (Table 1).

The highest Ag abundances were recorded in GCM2 where the value in distal granite is $11.7 \mathrm{ppm}$. This value is enriched to $>100 \mathrm{ppm}$ in both mineralized granites and malachite/chalcopyrite separate. The standard value of $\mathrm{Ag}$ in granite is $0.04 \mathrm{ppm}$. The $>100 \mathrm{ppm}$ value marked the upper detection limit of the equipment which means that the Ag values in these samples is higher than the $100 \mathrm{ppm}$. The standard average value of $U$ is 3.7 in granite, whereas a similar value of $3.7 \mathrm{ppm}$ was recorded in distal granite which is enriched to a range of $14.3-29.2$ with an average of $21.8 \mathrm{ppm}$ in the mineralized granite. The value is further enriched to $70.8 \mathrm{ppm}$ in the malachite/chalcopyrite separate. $\mathrm{Pb}$ content in the distal granite is $46 \mathrm{ppm}$ which is close to the average value of $49 \mathrm{ppm}$ in granite (Mason, 1966). This value is enriched to a range of $109-547 \mathrm{ppm}$ averaging 328 ppm in mineralized granite and this is further enriched to a value of $9,960 \mathrm{ppm}$ in the malachite/chalcopyrite separate. The average value of $\mathrm{Pb}$ in granite is $49 \mathrm{ppm}$ (Mason, 1966). V abundance in the distal granite is 37 ppm which increases to a range of $70-73$ in the mineralized granites. The value rose to $834 \mathrm{ppm}$ in the malachite/chalcopyrite separate.

\section{Discussion}

The epigenetic barite-copper veins of the study area are generally not extensive ranging between 15 $75 \mathrm{~m}$ long with widths varying between $3.4-5 \mathrm{~m}$. These characteristics are similar to those reported in the Middle Benue Trough where the barite veins vary in extend from few meters up to $1.5 \mathrm{~km}$ and having widths ranging from few centimeters to $8 \mathrm{~m}$ (Ford, 1989). The densities of the barite in this study vary from the range of $3.5-3.72 \mathrm{~g} / \mathrm{cm}^{3}$ in WBM to $4.47-5.58 \mathrm{~g} / \mathrm{cm}^{3}$ in GBM, this implies that GBM is purer compared to that of WBM. In Nigeria, 96\% of baryte requirement (RMR\&DC, 1996) is used as an essential component in the production of drilling mud which is very important in oil industry. The minimum barite density required for drilling mud is $4.25 \mathrm{~g} / \mathrm{cm}^{3}$ going by the American Petroleum Institute (API) standard. The GBM fulfilled this condition and in the past the veins were mined by artisanal miners and the barite transported to Macaba services oil drilling company, Port Harcourt, for use (Ibrahim Galadima Personal Communication)

Microscopic study of the altered sandstones proximal to the barite veins indicate barite occurring in irregular form filling-up the pore spaces between the quartz and microcline and within the fractures of these brittle minerals. This situation implies the permeation of barite-bearing hydrothermal solutions into the wall rocks (proximal host rocks) to the veins thereby depositing barite ore. Reflected light microcopy of the $\mathrm{Cu}$ mineralized granites from GCM1 and GCM2 show relicts chalcopyrite as the original primary sulphide mineral that altered to malachite and its associated limonite. Malachite is the $\mathrm{Cu}$-bearing mineral having a chemical formula of $\mathrm{Cu}(\mathrm{OH})_{2} \mathrm{CO}_{3}$ is a secondary mineral formed from the alteration of the chalcopyrite in the veins/veinlets in GCM1 and GCM2. Such veins/veinlets hosting the chalcopyrite were exposed to the processes of hydrolysis and oxidation near or at the surface of the earth. The chalcopyrite ores got dissolved by a flux of the slightly acidic rainfall or acidic groundwater. Resulting components were goethite/limonite and curprous ions that are dissolved in groundwater solution (Guilbert and park, Jr., 1986; Robb, 2005). The soluble Cu ions percolate downwards in the regolith profile and encounter progressively more reducing conditions just below the upper limit of the water table. $\mathrm{Cu}$ is then precipitated as various secondary minerals, the compositions of which reflect the groundwater composition as well as local $\mathrm{pH}$ and Eh in the supergene zone (Robb, 2005). The $\mathrm{Cu}$ minerals precipitated are complex and can include a variety of copper-carbonates, -silicates, -phosphates, - 
sulphates, -arsenates, as well as -oxyhydroxides phases (Chavez, 2000). Of relevance to the GCM1 and GCM2 is the interaction of $\mathrm{CO}_{3}{ }^{2-}$ rich groundwater with the $\mathrm{Cu}$ ions resulting into precipitation of malachite. The malachite and associated limonite which now almost wholly occupy the veins/veinlets occur as pseudomorphs after the chalcopyrite. Here also, malachite was mined in the pass by artisanal miners and the ore materials were transported to Lagos for onward shipment to overseas (Ibrahim Galadima personal communication).

Trace elements geochemistry indicates that the most important trace elements in the baryte mineralization areas are $\mathrm{Ba}, \mathrm{Sr}$, and $\mathrm{Rb}$. The GBM and $\mathrm{WBM}$ are characterized by remarkable enrichments of $\mathrm{Ba}$ and $\mathrm{Sr}$ in the unaltered sandstones (distal) through the altered (proximal) sandstones to the barite veins where Ba content is $>500,000(>50 \%)$ (Table 1$)$. This is apparently due barite mineralization. There is a positive correlation between $\mathrm{Ba}$ and $\mathrm{Sr}$ in these mineralization areas. However, there is a remarkable decrease of $\mathrm{Rb}$ abundances from the unaltered sandstones through to the barite veins which implied that the barite mineralization was accompanied by depletion of $\mathrm{Rb}$. In a similar study, Garba (2000) reported that the hornfels proximal to Bin Yauri Au mineralization in NW Nigeria, show enrichment of $\mathrm{K}, \mathrm{Rb}$ and Ba relative to the precursor phyllites and distal hornfels. In the copper mineralization areas, the most important trace elements are $\mathrm{Cu}, \mathrm{Ba}, \mathrm{Sr}$ and $\mathrm{Rb}$. Other significant elements include $\mathrm{Ag}, \mathrm{U}, \mathrm{V}, \mathrm{Zr} \mathrm{Pb}$ and $\mathrm{Y} . \mathrm{Cu}$ abundances in GCM1 and GCM2 were enriched attaining to levels $>10,000 \mathrm{ppm}(>1 \%)$ in copper mineralized granites and chalcopyrite/malachite separate (Table 1). This enrichment is due to $\mathrm{Cu}$ mineralization that abounds in the secondary mineral malachite. It is noted that the $\mathrm{Cu}$ mineralization in both areas are in general accompanied by depletion of $\mathrm{Ba}, \mathrm{Sr}, \mathrm{Rb}$ and enrichment of $\mathrm{Ag}, \mathrm{U}, \mathrm{V}, \mathrm{Zr} \mathrm{Pb}$ and $\mathrm{Y}$ from the distal granite through altered granites to mineralized granites and malachite/chalcopyrite separate. The hydrothermal fluids responsible for depositing $\mathrm{Cu}$ were enriched in $\mathrm{Ag}, \mathrm{U}, \mathrm{V}, \mathrm{Zr} \mathrm{Pb}$ and $\mathrm{Y}$ which may indicate high chemical activity of the fluids which chemically attacked and leached the host granites thereby concentrating these elements in the hydrothermal solutions which subsequently deposited them along with the $\mathrm{Cu}$. However, these elements occur in their background values in the baryte mineralization areas. A clear contrast in the behavior and enrichment of the important trace elements between the barite and copper mineralization areas is revealed. In the baryte mineralization areas, $\mathrm{Ba}$ and $\mathrm{Sr}$ are enriched but $\mathrm{Rb}$ is depleted from the distal sandstones through the proximal sandstones to the barite veins. On the other hand, in the copper mineralization area, these three elements are depleted while $\mathrm{Cu}, \mathrm{Ag}, \mathrm{U}, \mathrm{V}, \mathrm{Zr}, \mathrm{Pb}$ and $\mathrm{Y}$ are enriched in the distal granite through proximal granites to enriched granites and malachite/chalcopyrite separate. The above variations observed in the two mineralization areas may be due to variation in source or origin of the mineralizing hydrothermal solutions. EL-Nafaty (2015b) has earlier reported that the sulphur source of the barite separates (which were the same as those discussed in this work) yielded stable sulphur ${ }^{24} \mathrm{~S}$ isotope composition of $12.3-13.1 \%$ (CDT). These values reflect sedimentary formational water source of the sulphur. Although the same $\mathrm{Cu}$-mineralized granites and chalcopyrite/malachite separate of this work were also analysed for ${ }^{34} \mathrm{~S}$ isotope but no peaks were obtained to determine the source of the sulphides (EL-Nafaty, 2015b). Therefore, the origin of the mineralizing fluids of the baryte and copper mineralization areas might be different thereby resulting in different kinds of trace elements behavior and enrichment in each of these mineralization areas. These differences in the behavior and trace element abundances of the two mineralizations areas might also be as a result of variation in host rocks (sandstones and granites) and/or hydrothermal solutions compositions that are responsible for depositing barite and copper mineralizations. The variations might also be brought about by differences in temperatures of the mineralizing fluids as well as chemical activity on intensity of the hydrothermal solutions.

The ore component of $\mathrm{Ba}$ responsible for the barite mineralization sub-system could have been leached from the sandstones host rocks. It is observed that the Ba values in the distal sandstones are enriched having an average value of $1536 \mathrm{ppm}(\mathrm{n}=4)$ in GBM and $1640 \mathrm{ppm}(\mathrm{n}=1)$ in WBM (Table 1), the crustal average Ba content is $425 \mathrm{ppm}$. The $\mathrm{Ba}$ is probably from diagenetic barite in the sandstones which must have been leached by the invading hydrothermal fluid thereby reacting with sulphate in the fluid and precipitating barite at appropriate structural sites (Griffith and Paytan, 2012). On the other hand, the Cu components and other associated enriched elements responsible for the formation of chalcopyrite veins in the copper mineralization area might have been released through the scavenging of these elements from the host granites by the invading hydrothermal solutions. The host granites in places might have contained disseminated sulphides, some few chalcopyrite disseminations have been observed in microcline and even quartz crystals in the altered and mineralized granites as revealed by the reflected light microscopy of these rocks. Geochemical data in this work (Table 1) show that the distal granite in GCM1 gave $20 \mathrm{ppm} \mathrm{Cu}$ while that of GCM2 recorded 1180 ppm which is high when compared to a value of $13 \mathrm{ppm}$ for standard granite. It is therefore possible that $\mathrm{Cu}$ which occur as disseminations in the granites might have been remobilized and carried into the hydrothermal fluid thereby reacting with the fluid components and subsequently precipitating the sulphide ores (chalcopyrite) at favorable structural sites in the granites. 


\section{Conclusion}

The barite-copper mineralizations of the Gulani area are typical fracture filling hydrothermal mineralizations that are similar to those located in the Middle Benue Trough (Farrington, 1952; Akande and Abimbola, 1987 and Ford, 1989). Field and petrographic study of the host rocks both the sandstones and granites and their brittle essential minerals of quartz and microcline appear fractured which aided the permeation of the hydrothermal solution responsible for the mineralizations. The original sulphide (chalcopyrite) veins/veinlets of the copper mineralization areas have largely been altered or transformed into malachite and its associated limonite through the processes of hydrolysis and oxidation. These veins/veinlets are now almost fully occupied by these secondary minerals and few relicts chalcopyrite. However, the copper of these mineralization areas is entirely associated with the malachite. Trace elements geochemistry indicates enrichment of $\mathrm{Ba}$ and $\mathrm{Sr}$ and depletion of $\mathrm{Sr}$ in the barite mineralization areas whereas in the copper mineralization area $\mathrm{Ba}, \mathrm{Sr}$ and $\mathrm{Rb}$ were depleted while there was enrichment of $\mathrm{Ag}, \mathrm{U}, \mathrm{V}, \mathrm{Zr}, \mathrm{Pb}$ and $\mathrm{Y}$ associated with the mineralization.

\section{Acknowledgements}

I am grateful to the former heads of Department of Geology, Ahmadu Bello University, Zaria, Nigeria and Kano State University of Science and Technology, Wudil, Nigeria, in persons of Prof. U. A. Danbatta and Dr. A. A. Ibrahim for their help and allowing the use of their laboratory facilities. I am thankful to Prof. S. Baba of the Department of Geology, University of Maiduguri for going through the draft manuscript and making useful observations and suggestions.

\section{References}

[1]. Abaa, S. I. 2009.Quality status of Nigerian's solid mineral resources as raw materials for the oil industry. Paper presented at a workshop organized by the Nigerian geological survey, Abuja, $22 \mathrm{P}$.

[2]. Adubok, A. S. and Imoekparia, E. G. 2008. Trace elements distribution and enrichment in soils overlying baryte vein deposits in the Paya district, middle Benue Trough, Nigeria. Continental Journal of Earth sciences, 3, PP. 22-27.

[3]. Ajayi, C. O. 1987. Origin of saltsprings and barytes in the middle Benue Trough: A suggested model from gravity data. In: Matheis, G. \& Schandelmeier, H. (eds.), Current research in African earth sciences. Balkema, Rotterdam. PP. 455 - 456.

[4]. Akande, S. O. and Abimbola, A. F. 1987. Aspects of the genesis of lead - zinc - fluorine - baryte mineralization in the Nigerian Benue Trough. In: Matheis, G. \& Schandelmeier, H. (eds.) Current research in African earth sciences. Balkema, Rotterdam. PP. 365 -369 .

[5]. Carter, J. D., Barber, D. F. M. and Tait, E.A. 1963. The Geology of parts of Adamawa, Bauchi and Bornu provinces in Northeastern Nigeria. Geological survey of Nigeria, bulletin No 30.

[6]. Chaanda, M. S., Obaje, N. G., Moumouni, A., Goki, N. G. and Lar U. A. 2010. Environmental impact of artisanal mining of barytes in Azara, middle Benue Trough, Nigeria. Online Journal of Earth sciences, 4, 1, PP. 38 - 42.

[7]. Chavez, W.X. 2000. Supergene oxidation of copper deposits: zoning and distribution of copper oxide minerals. Society of Economic Geologists Newsletter, 41.

[8]. EL-Nafaty, J. M. 2014. Geology, geochemistry and mineralization of Gulani area, Northeastern Nigeria. Unpublished Ph.D thesis, Department of Geology, University of Maiduguri, 163 P.

[9]. EL-Nafaty, J. M. 2015a. Geology and the petrography of the rocks around Gulani area, Northeastern Nigeria. Journal of Geology and Mining Research, 7, 5, PP $41-57$.

[10]. EL-Nafaty, J. M. 2015b. Rare earth element and stable sulphur $\left(\delta^{34}\right.$ S) isotope study of baryte-copper mineralization in Gulani area, Upper Benue Trough, NE Nigeria. Journal of African Earth Sciences, 106, PP 147 - 157.

[11]. Farrington, J. L. 1952. A preliminary description of the Nigerian lead-zinc field. Economic Geology, 47, 6, PP,583-608.

[12]. Ford, S. O. 1989. The economic mineral resources of the Benue Trough. In: Kogbe, C. A. (ed.), Geology of Nigeria. Rock view (Nig.) Ltd, Jos, second revised edition, PP. $473-484$.

[13]. Garba, I. 2000. Origin of Pan-African mesothermal gold mineralization at Bin Yauri, Nigeria. Journal of African Earth Sciences. 31, PP $433-449$.

[14]. Griffith, E.M. and Paytan, A. 2012. Barite in the ocean - occurrences, geochemistry and palaeoceanographic applications. Sedimentology, 10, PP. $1-19$.

[15]. Guilbert, J. M. and Park Jr; C. F. 1986. The geology of ore deposits. Freeman, W. H. \& Comp; New York, 985 PP

[16]. Hibbard, M. J. 2002. Mineralogy: A geologist's point of view. McGraw Hill, New York, 562 PP.

[17]. Mason, B. 1966. Principles of geochemistry. Third edition, John Wiley and Sons, Inc., New York, 328 P.

[18]. Olade, M.A. 1976. On the genesis of lead-zinc deposits in Nigeria's Benue Rift (aulacogen) - a re-interpretation. Journal of Mining and Geology. 13, 2, PP 20-27.

[19]. Olade, M. A. and Marton, R. D. 1980. Temperatures of ore formation and origin of the Ishiagu Lead-zinc deposit, southern Benue Trough, Nigeria. Journal of mining and geology, 17, PP $119-127$.

[20]. Popoff, M., Wiedmann, J. and de KLasz, I. 1986. The Upper Cretaceous Gongila and Pindiga Formations, northern Nigeria: subdivisions, age, stratigraphic correlations and paleogeographic implications. Eclogue geologicae helvetiae, 79, PP $343-363$.

[21]. Raw Material Research and Development Council (RMR\&DC), 1996. Technical brief on minerals in Nigeria: Baryte. 17 P.

[22]. Raw Materials Research and Development Council (RMR\&DC), 2004.technical brief No. 16, Lead/zinc. 23 P.

[23]. Riley, C. M. 1959. Our mineral resources, John Wiley \& Sons, Inc. New York, 338 P.

[24]. Robb, L. 2005. Introduction to ore-forming processes, Blackwell publishing, Oxford, U. K, 373 P.

[25]. Tate, R. B. 1959. Memorandum of the Geological Survey of Nigeria on the baryte deposits of the Benue Province. Unpublished report No. 1266.

[26]. Wright, J. B. 1989. Volcanic rocks in Nigeria. In: Kogbe C. A. (ed.), Geology of Nigeria, Rock view (Nigeria) Ltd, Jos, PP 125 173.

[27]. Zaborski, P., Ugodulunwa, F., Idornigie, A., Nnabo, P. and Ibe, K. 1997. Stratigraphy and structure of the Cretaceous Gongola Basin, Nigeria. Bulletin centres recherhes exploration-production Elf-Aquitaine 21, PP. 154 - 184. 